\title{
The Synaptic Targeting of mGluR1 by Its Carboxyl-Terminal Domain Is Crucial for Cerebellar Function
}

\author{
Yoshiaki Ohtani, ${ }^{1 \star}$ Mariko Miyata, ${ }^{2,3,4 \star}$ Kouichi Hashimoto, ${ }^{4,5}$ Toshihide Tabata, ${ }^{6}$ Yasushi Kishimoto, ${ }^{7}$ \\ Masahiro Fukaya, ${ }^{8}$ Daisuke Kase, ${ }^{2}$ Hidetoshi Kassai, ${ }^{1,9}$ Kazuki Nakao, ${ }^{9,10}$ Tatsumi Hirata, ${ }^{11}$ Masahiko Watanabe, ${ }^{12}$ \\ Masanobu Kano, ${ }^{5}$ and Atsu Aiba ${ }^{1,9}$ \\ ${ }^{1}$ Division of Molecular Genetics, Kobe University Graduate School of Medicine, Kobe 650-0017, Japan, 2Department of Information Physiology, National \\ Institute for Physiological Sciences, Okazaki 444-8585, Japan, ${ }^{3}$ Department of Physiology, School of Medicine, Tokyo Women's Medical University, Tokyo \\ 162-8666, Japan, ${ }^{4}$ PRESTO, Japan Science and Technology Agency, Saitama 332-0012, Japan, ${ }^{5}$ Department of Neurophysiology, Graduate School of \\ Medicine, The University of Tokyo, Tokyo 113-0033, Japan, ' Laboratory for Neural Information Technology, Graduate School of Sciences and Engineering, \\ University of Toyama, Toyama 930-8555, Japan, ${ }^{7}$ Laboratory of Neurobiophysics, Kagawa School of Pharmaceutical Sciences, Tokushima Bunri University, \\ Kagawa 769-2193, Japan, ${ }^{8}$ Department of Anatomy, Kitasato University School of Medicine, Sagamihara 252-0374, Japan, ${ }^{9}$ Laboratory of Animal Resources, \\ Center for Disease Biology and Integrative Medicine, Faculty of Medicine, The University of Tokyo, Tokyo 113-0033, Japan, ${ }^{10}$ RIKEN Center for \\ Developmental Biology, Kobe 650-0047, Japan, ${ }^{11}$ Division of Brain Function, National Institute of Genetics, Graduate University for Advanced Studies, \\ Shizuoka 411-8540, Japan, and ${ }^{12}$ Department of Anatomy, Hokkaido University Graduate School of Medicine, Sapporo 060-8638, Japan
}

The metabotropic glutamate receptor subtype 1 (mGluR1, Grm1) in cerebellar Purkinje cells (PCs) is essential for motor coordination and motor learning. At the synaptic level, mGluR1 has a critical role in long-term synaptic depression (LTD) at parallel fiber (PF)-PC synapses, and in developmental elimination of climbing fiber (CF)-PC synapses. mGluR1a, a predominant splice variant in PCs, has a long carboxyl (C)-terminal domain that interacts with Homer scaffolding proteins. Cerebellar roles of the $\mathrm{C}$-terminal domain at both synaptic and behavior levels remain poorly understood. To address this question, we introduced a short variant, mGluR1b, which lacks this domain into PCs of mGluR1-knock-out (KO) mice (mGluR1b-rescue mice). In mGluR1b-rescue mice, mGluR1b showed dispersed perisynaptic distribution in PC spines. Importantly, mGluR1b-rescue mice exhibited impairments in inositol 1,4,5-trisphosphate receptor $\left(\mathrm{IP}_{3} \mathrm{R}\right)$-mediated Ca ${ }^{2+}$ release, $\mathrm{CF}$ synapse elimination, LTD induction, and delay eyeblink conditioning: they showed normal transient receptor potential canonical (TRPC) currents and normal motor coordination. In contrast, PC-specific rescue of mGluR1a restored all cerebellar defects of mGluR1-KO mice. We conclude that the long C-terminal domain of mGluRla is required for the proper perisynaptic targeting of mGluR1, $\mathrm{IP}_{3} \mathrm{R}$-mediated Ca ${ }^{2+}$ release, $\mathrm{CF}$ synapse elimination, LTD, and motor learning, but not for TRPC currents and motor coordination.

Key words: cerebellum; eyeblink conditioning; LTD; mGluR1; Purkinje cells; synapse elimination

\section{Introduction}

The metabotropic glutamate receptor subtype 1 (mGluR1, Grm1) is richly expressed in cerebellar Purkinje cells (PCs) and

\footnotetext{
Received Aug. 18, 2013; revised Dec. 13, 2013; accepted Jan. 13, 2014.

Author contributions: M.K. and A.A. designed research; Y.O., M.M., K.H., T.T., Y.K., M.F., D.K., H.K., K.N., and M.W. performed research; T.H. contributed unpublished reagents/analytic tools; Y.O., M.M., K.H., T.T., Y.K., M.F., D.K., H.K., and M.W. analyzed data; M.M., M.K., and A.A. wrote the paper.

This work has been supported by Grants-in-Aid for Scientific Research (16015281 and 17024038 to A.A.; 17023021, 21220006, and 21650094 to M.K.; 20021029 to M.M.; 22300125 to K.H.; 19045019,20022025 , 20500284, 21026011, and 23500384 to T.T.; 20790084 to Y.K.), JST PRESTO program, Takeda Science Foundation, the Strategic Research Program for Brain Sciences (Development of Biomarker Candidates for Social Behavior), and the Global COE Program (Integrative Life Science Based on the Study of Biosignaling Mechanisms) from MEXT, Japan. We thank Dr. Shigetada Nakanishi for rat mGluR1a CDNA, Dr. John Oberdick for the $L 7$ gene cassette, and Dr. Yasumasa Ishida for $\beta$-globin insulator.

The authors declare no competing financial interests.

*Y.O. and M.M. contributed equally to this work.

Correspondence should be addressed to Dr. Atsu Aiba, Laboratory of Animal Resources, Center for Disease Biology and Integrative Medicine, Faculty of Medicine, The University of Tokyo, 7-3-1 Hongo, Bunkyo-ku, Tokyo 113-0033, Japan. E-mail: aiba@m.u-tokyo.ac.jp.

K. Hashimoto's present address: Department of Neurophysiology, Graduate School of Biomedical Sciences, Hiroshima University, Hiroshima 734-8551, Japan.

DOI:10.1523/JNEUROSCI.3542-13.2014

Copyright $\odot 2014$ the authors $\quad 0270-6474 / 14 / 342702-11 \$ 15.00 / 0$
}

has a critical role in cerebellar function, including motor learning and motor coordination. Binding of glutamate to the receptor activates phospholipase $\mathrm{C} \beta$ (PLC $\beta$ ), via heterotrimeric G-proteins $\mathrm{Gq} /$ $G_{11}$, leading to generation of inositol 1,4,5-trisphosphate $\left(\mathrm{IP}_{3}\right)$ and diacylglycerol. Synaptic activation of mGluR1 in PCs results in two cellular responses: $\mathrm{IP}_{3}$ receptor $\left(\mathrm{IP}_{3} \mathrm{R}\right)$-mediated $\mathrm{Ca}^{2+}$ release from smooth endoplasmic reticulum (SER) and transient receptor potential canonical (TRPC)-mediated currents by diacylglycerol. Simultaneous elevation of $\mathrm{Ca}^{2+}$ concentration in cytoplasm and diacylglycerol levels activates PKC. These mGluR1 signaling molecules play crucial roles in development, modulation, and plasticity of cerebellar synapses as well as motor learning and motor coordination (Ito, 2001; Kano and Hashimoto, 2009).

Alternative splicing generates at least three variants of mGluR1: mGluR1a $(1 \alpha), 1 \mathrm{~b}(1 \beta)$, and $1 \mathrm{~d}(1 \gamma)$. They can be divided into two groups according to the lengths of their intracellular carboxyl (C)-terminal domains (Ferraguti et al., 2008). mGluRla has a long C-terminal domain that can interact with Homer proteins (Brakeman et al., 1997), whereas mGluR1b and 
1d have short C-terminal domains. mGluRla predominates in the cerebellum and olfactory bulb, whereas short variants are the major isoforms in other areas (Fotuhi et al., 1993). Both mGluR1a and short splice variants, including mGluR1b, are expressed in PCs. It has been suggested that the long C-terminal domain might play a role in translocation of mGluR1 to the plasma membrane and clustering of the receptor in cultured cells (Francesconi and Duvoisin, 2002; Das and Banker, 2006). In terms of signal transduction, the $\mathrm{IP}_{3} \mathrm{R}$-mediated $\mathrm{Ca}^{2+}$ response can be detected in cultured cells ectopically expressing either mGluR1a or mGluR1b (Pickering et al., 1993), but the long C-terminal domain enables better PLC coupling efficacy (Prézeau et al., 1996; Mary et al., 1998). Thus, the long C-terminal domain does not seem to be essential but plays a regulatory role in the Gq-PLC $\beta-\mathrm{IP}_{3} \mathrm{R}$ pathway. In contrast, roles of the long C-terminal domain in localization of mGluR1 in spines, mGluR1mediated $\mathrm{Ca}^{2+}$ release, and TRPC-mediated currents at PC synapses have yet to be examined. Furthermore, whether the long C-terminal domain is crucial for cerebellar long-term depression (LTD), developmental synapse elimination, motor coordination, and motor learning has not yet been clarified.

To examine roles of the long C-terminal domain of mGluRla in cerebellar function at synaptic and behavioral levels, we introduced mGluR1a or mGluR1b transgenes into mGluR1-knockout $(\mathrm{KO})$ mice with a PC specific promoter. We found that the long C-terminal was essential for proper targeting of mGluR1 in $\mathrm{PC}$ spines, $\mathrm{IP}_{3} \mathrm{R}$-mediated $\mathrm{Ca}^{2+}$ release from SER in PCs, LTD induction, CF synapse elimination, and delay eyeblink conditioning. In contrast, the long C-terminal domain was not necessary for TRPC-mediated current in PCs and motor coordination, which can be managed by mGluR1b. We therefore report that different signal transduction pathways mediated by a single receptor in a single-cell type are responsible for distinct brain functions at both synaptic and behavioral levels.

\section{Materials and Methods}

Transgenic mice. Animal experiments were conducted in accord with local ethical guidelines (Kobe University Graduate School of Medicine, Kanazawa University Graduate School of Medicine, National Institute for Physiological Sciences, Hokkaido University School of Medicine, and RIKEN Center for Developmental Biology).

Animals were housed at $21 \pm 1^{\circ} \mathrm{C}$ with free access to food and water. The mGluR1-KO ( $\left.m G l u R 1^{-/-}\right)$mice (originally kept on a mixed $129 / \mathrm{Sv}$ $\mathrm{X}$ C57BL/6 background) had been backcrossed more than eight times with C57BL/6. We generated transgenic mice $(L 7-m G l u R 1 b)$ that expressed $m G l u R 1 b$ encoding 906 amino acid residues under the control of the Purkinje cell-specific L7 promoter (Oberdick et al., 1990) as described previously (Ichise et al., 2000). $m G l u R 1 b \mathrm{cDNA}$ was constructed by replacing a C-terminal region of rat mGluRla cDNA with an mGluR1b-specific sequence (Masu et al., 1991; Tanabe et al., 1992). The $m G l u R 1 b$ cDNA was introduced into exon 4 of the $L 7$ gene cassette. We obtained 5 independent $L 7-m G l u R 1 b$ transgenic founder mice by microinjecting the transgene into the pronuclei of fertilized $m G l u R 1^{+/-}$eggs. The mGluR1b-rescue mice were obtained by breeding $m G l u R 1^{+/-}$mice with transgenic mice. Mice of either sex were used for all experiments.

In situ hybridization. In situ hybridization analysis was performed using splice variant-specific antisense oligonucleotide probes for the mGluR1 mRNAs. Under deep pentobarbital anesthesia, brains were freshly obtained from wild-type (WT), mGluR1-KO, mGluR1a-rescue, and mGuR1b-rescue mice. Fresh frozen sections (20 $\mu \mathrm{m}$ thickness) were cut with a cryostat (CM1900, Leica) and mounted on glass slides precoated with 3-aminopropyltriethoxysilane. Probe labeling and hybridization were performed as described previously (Fukaya et al., 2005) with minor modifications. Probes for in situ hybridization were synthesized as follows: 5'-ggtgttggagcggcacggcagtttgccatcaccgacgtgcatgcg-3' for pan
mGluR1 ( $m$ GluR1a/1b) (nucleotide residues 2945-2989, GenBank accession numberNM_017011),5' -gaggaggaggcaagcccttggggtagacagaatcagcca ggaaca-3' for $m$ GluR1a (nucleotide residues 3431-3475, GenBank accession number NM_016976), 5' -gctgcgcatgtgccgacggacactggctgctgggcgag aattctg-3' for $m G l u R 1 b$ (nucleotide residues 3090-3134, GenBank accession number BC079566). Hybridization was performed at $42^{\circ} \mathrm{C}$ for $12 \mathrm{~h}$ in prehybridization buffer supplemented with $10,000 \mathrm{cpm} / \mu \mathrm{l}$ of $\left[{ }^{33} \mathrm{P}\right]$ dATP-labeled oligonucleotide probes. Slides were washed twice at $55^{\circ} \mathrm{C}$ for $40 \mathrm{~min}$ in $0.1 \times$ SSC containing $0.1 \%$ sarcosyl. Sections were exposed either to BioMax (Kodak) or to Nuclear Track emulsion (NTB-2, Kodak) for 4 weeks. Emulsion-dipped sections were Nisslstained with methyl green pyronine solution.

Immunofluorescence. In the present study, we used rabbit antimGluR1a antibody (Tanaka et al., 2000), and we also produced rabbit anti-mGluR1b antibody. The C-terminal peptide of mouse mGluR1b (CPSAHVQL, GenBank accession number BC079566) was obtained as a GST fusion protein using pGEX-4T-2 plasmid (GE Healthcare). Procedures for immunization and antibody purification were reported previously (Nakamura et al., 2004). Under deep pentobarbital anesthesia (100 $\mathrm{mg} / \mathrm{kg}$ of body weight), WT, mGluR1-KO, mGluR1a-rescue, and mGluR1b-rescue mice at 1 month of age were perfused transcardially with $4 \%$ PFA in $0.1 \mathrm{~m}$ sodium phosphate buffer, $\mathrm{pH}$ 7.4. Microslicer cerebellar sections (20 $\mu \mathrm{m}$ in thickness) were incubated overnight at room temperature with guinea pig anti-mGluRla or rabbit antimGluR 1 b antibody followed by $2 \mathrm{~h}$ incubation with Cy3-labeled donkey anti-rabbit or guinea pig IgG (1:200, Jackson ImmunoResearch Laboratories). We also used hematoxylin staining to check cerebellar structure.

Postembedding immunogold microscopy. For postembedding immunogold microscopy, cerebellar specimens fixed with $4 \%$ PFA/0.1\% glutaraldehyde in $0.1 \mathrm{~m}$ phosphate buffer, $\mathrm{pH} 7.4$, were cryoprotected with $30 \%$ sucrose in $0.1 \mathrm{M}$ phosphate buffer, and frozen rapidly with liquid propane in a Leica EM CPC unit. Frozen sections were immersed in $0.5 \%$ uranyl acetate in methanol at $-90^{\circ} \mathrm{C}$ in a Leica AFS freeze-substitution unit, infiltrated at $-45^{\circ} \mathrm{C}$ with Lowicryl $\mathrm{HM}-20$ resin (Lowi), and polymerized with UV light. After etching with saturated sodium-ethanolate solution for $3 \mathrm{~s}$, ultrathin sections on nickel grids were treated successively with $1 \%$ human serum albumin (Wako)/0.1\% Triton X-100 in Tris-buffered saline (HTBST pH 7.5) for $1 \mathrm{~h}$, primary antibodies $(15 \mu \mathrm{g} / \mathrm{ml}$ ) in HTBST overnight, and colloidal gold $(10 \mathrm{~nm})$-conjugated anti-rabbit or antiguinea pig IgG (1:100, British Bio Cell International) in HTBST for $2 \mathrm{~h}$. Finally, grids were stained with uranyl acetate for $15 \mathrm{~min}$ and examined with an H-7100 electron microscope (Hitachi). For quantitative analysis, distribution of immunogold particles on PC spines of PF-PC synapses was counted and analyzed using IPLaboratory software (Nippon Roper).

Preparation of synaptosomal fraction and coimmunoprecipitation. The synaptosomal fraction was prepared from mouse cerebellum essentially as described by Huttner et al. (1983). Mouse cerebellum was isolated and homogenized in a buffer containing $10 \mathrm{~mm}$ Tris- $\mathrm{HCl}, \mathrm{pH} 7.4,0.32 \mathrm{~m}$ sucrose, and protease inhibitor mixture (Roche). The suspension was centrifuged at $1000 \times g$ for $10 \mathrm{~min}$, and the supernatant was centrifuged again at $10,000 \times g$ for $20 \mathrm{~min}$. The sediment (synaptosomal fraction) was solubilized in a lysis buffer $(50 \mathrm{~mm}$ Tris- $\mathrm{HCl}, \mathrm{pH} 7.4,150 \mathrm{~mm} \mathrm{NaCl}$, $1 \%$ NP-40, and protease inhibitor mixture), followed by centrifugation at $20,000 \times g$ for $30 \mathrm{~min}$. For coimmunoprecipitation, the resultant supernatant was incubated overnight with rat monoclonal antibody to the extracellular domain of mGluR1 (lot1 antibody) (Hirata et al., 2012) or rat IgG, which were coupled to CNBr-activated Sepharose. Subsequently, the Sepharose was washed three times with $1 \mathrm{ml}$ of lysis buffer, and bound proteins were immunoblotted using antibodies against the extracellular domain of mGluR1 (a gift from Dr. Araishi, Kanazawa University Graduate School of Medicine, Kanazawa, Japan), Homer (Santa Cruz Biotechnology), GluR $\delta 2$ (Millipore Bioscience Research Reagents), $\mathrm{GABA}_{\mathrm{B}} \mathrm{R} 2$ (BD Transduction Laboratories), and $\mathrm{Ca}_{\mathrm{v}} 2.1$ (Alomone Labs).

Cation current measurements and calcium imaging in cultured PCs. Neonatal C57BL/6 pups were deeply anesthetized by cooling in chilled PBS and then decapitated. The cerebella from these pups were dissociated with trypsin and plated onto plastic dishes (diameter, $35 \mathrm{~mm}$; Falcon 3001) or low-fluorescence plastic films (Sumilon, MS-92132, Sumitoto), and maintained in a hormone-supplemented, low-serum medium. So- 
matic perforated-patch whole-cell recordings were made from PCs cultured on the dish for 12-17 d (series resistance, 20-80 $\mathrm{M} \Omega$ ), using voltage-clamp amplifier (EPC9/2, HEKA) as described previously (Tabata et al., 2000). The pipette solution consisted of (in mM) $95 \mathrm{Cs}_{2} \mathrm{SO}_{4}, 15$ $\mathrm{CsCl}, 0.4 \mathrm{CsOH}, 8 \mathrm{MgCl}_{2}, 10 \mathrm{HEPES}$, and $200 \mu \mathrm{g} / \mathrm{ml}$ amphotericin B, $\mathrm{pH}$ 7.35. The recording chamber (culture dish) was perfused at a rate of 1-2 $\mathrm{ml} / \mathrm{min}$ with saline, which consisted of (in $\mathrm{mm}$ ) $116 \mathrm{NaCl}, 5.4 \mathrm{KCl}, 1.1$ $\mathrm{NaH}_{2} \mathrm{PO}_{4}, 23.8 \mathrm{NaHCO}_{3}, 2 \mathrm{CaCl}_{2}, 0.3 \mathrm{MgCl}_{2}, 5.5 \mathrm{D}$-glucose, and 5 HEPES, pH 7.3, at $25^{\circ} \mathrm{C}$. Voltage-gated $\mathrm{Na}^{+}$channels and ionotropic receptors for glutamate and GABA were always blocked by supplementing the saline with (in $\mu \mathrm{M}$ ): 0.3 tetrodotoxin, 10 2,3-dioxo-6-nitro-1, 2,3,4-tetrahydrobenzo[f] quinoxaline-7-sulfomide, $50 \mathrm{D}(-)$-2-amino5-phosphonopentanoic acid, and 10 (-)-bicuculine methochloride. We set the holding potential to $50 \mathrm{mV}$ to inactivate the voltage-gated channels and recorded the cation current as an outward current. We first measured the maximal outward deflection during a $30 \mathrm{~s}$ application of $500 \mu \mathrm{M}$ R,S-3,5-dihydroxyphenylglycine (DHPG) in the WT and mGluR1b-rescue cells (see Fig. 7A). Because the absolute amplitudes in cultured PCs showed considerable cell-to-cell variability, we compared the DHPG dose-response relation of the relative amplitudes of the cation currents for the tested range of $0.5 \mathrm{~nm}$ to $500 \mu \mathrm{M}$ (see Fig. 7B).

PCs cultured on the film for 13-14 d were loaded with fura-2, a Ca ${ }^{2+}$ indicator by incubation with fura- 2 acetoxymethyl ester $\left(5 \mu \mathrm{M}, 37^{\circ} \mathrm{C}\right.$, 10-20 min). Then, film was placed on a glass-based recording chamber and perfused at a rate of $1-2 \mathrm{ml} / \mathrm{min}$ with blocker-containing saline (see above). $\left[\mathrm{Ca}^{2+}\right]_{\mathrm{i}}$-dependent fluorescence signals excited at 340 and 380 $\mathrm{nm}$ (100 and $50 \mathrm{~ms}$, respectively) were captured at $2 \mathrm{~Hz}$, using an imaging system (Polychrome II, TILL) attached to an inverted microscope (NA = 0.75; IX70, Olympus).

Electrophysiology in cerebellar slices. Parasagittal cerebellar slices (250 $\mu \mathrm{m}$ thickness) were prepared from WT, mGluR1KO, mGluR1a-rescue, and mGluR1b-rescue mice aged at P36-P71. The procedures described by Kano et al. (1997) and Miyata et al. (2000) were used to examine synaptic responses and to count the number of discrete steps of CFEPSCs from PCs. In brief, PCs were visualized using an upright microscope (BX50WI; Olympus) with or without an infrared video system (C2400-79H, Hamamatsu Photonics). Whole-cell recordings were made with a patch-clamp amplifier EPC9 (HEKA Electronik) or Axopatch-1D (Molecular Devices) for voltage-clamp recordings. For current-clamp recordings, Axoclamp 2B (Molecular Devices) was used. Resistances of patch pipettes were 2-6 $\mathrm{M} \Omega$ when filled with an intracellular solution composed of (in mM): $60 \mathrm{CsCl}, 10 \mathrm{Cs}$ D-gluconate, 20 TEA-Cl, 20 BAPTA, $4 \mathrm{MgCl}_{2}$, 4 ATP, $0.4 \mathrm{GTP}$, and 30 HEPES, pH 7.3, adjusted with $\mathrm{CsOH}$ for voltage-clamp recordings and $120 \mathrm{~K}$-gluconate, $10 \mathrm{HEPES}, 1.0$ EGTA, $2 \mathrm{MgCl}_{2}, 0.1 \mathrm{CaCl}_{2}, 10 \mathrm{NaCl}, 2 \mathrm{Na}_{2} \mathrm{ATP}$, and $0.5 \mathrm{Na}_{2} \mathrm{GTP}$, pH 7.3, adjusted with $\mathrm{KOH}$ for current-clamp recordings. Signals were filtered at $3 \mathrm{kHz}$ and digitized at $20-50 \mathrm{kHz}$ for recording. All experiments were performed at $30^{\circ} \mathrm{C}-32^{\circ} \mathrm{C}$ in the presence of $10 \mu \mathrm{M}(-)$-bicuculline methobromide (Tocris Cookson), an antagonist of $\mathrm{GABA}_{\mathrm{A}}$ receptors (Kano et al., 1997; Miyata et al., 2000). Liquid-junction potentials between the internal solutions and ACSF were corrected. Bridge balances and capacitances were compensated under a current-clamp configuration.

For recording LTD under the current-clamp condition, a small negative current was applied through the recording pipette to hold the potential at $\sim-65 \mathrm{mV}$, thus avoiding spontaneous PC firing. EPSPs were evoked using a concentric electrode (tip diameter, $25 \mu \mathrm{m}$; Inter Medical). The stimulus consisted of a $100 \mu$ s duration bipolar pulse of constant current steps $(<100 \mu \mathrm{A})$ using a biphasic isolator (BAK Electronics). The test stimulus was delivered at $0.05 \mathrm{~Hz}$.

For recording mGluR1-mediated slow EPSCs, we first adjusted the stimulus strength such that approximately the same number of PFs was stimulated in mGluRla-rescue and mGluR1b-rescue mice. We set the stimulus intensity ( $100 \mu$ s duration) to evoke $\sim 350$ pA PF-EPSCs in the normal ACSF with $10 \mu \mathrm{M}(-)$-bicuculline methobromide. Then, CNQX $(50 \mu \mathrm{M})$ was added to block AMPA receptor-mediated PF-EPSCs for recording mGluR1-mediated slow EPSCs. An intracellular solution containing (in mM) 135 Cs-methanesulphonate, $10 \mathrm{CsCl}, 10 \mathrm{HEPES}, 4 \mathrm{ATP}$ $2 \mathrm{Na}, 0.4 \mathrm{GTP}-\mathrm{Na}$, and 0.2 EGTA was used. The holding potential was set at $-70 \mathrm{mV}$, and series resistance was compensated to $8-12.5 \mathrm{M} \Omega$. A stimulation glass pipette $(1-2 \mathrm{M} \Omega$ ) was filled with ACSF and placed in the molecular layer at the two-thirds of its thickness from the PC layer. To identify the effect of the stimulus frequency on the mGluR-mediated slow EPSCs, the number of train pulses was fixed to 10 pulses while the frequency was changed from 12.5 to $400 \mathrm{~Hz}$.

Data were acquired using the PULSE program (HEKA, version 8.2 and 8.54), and off-line analysis was performed by Pulse Fit (HEKA, version 8.54, Electronik) and Igor Pro (Wavemetrics). All antagonists were purchased from Tocris Cookson.

Calcium imaging in cerebellar slices. PCs were loaded for at least $20 \mathrm{~min}$ with a $\mathrm{Ca}^{2+}$ indicator (Oregon Green 488 BAPTA-1, Invitrogen; 100 $\mu \mathrm{M})$ through a patch pipette filled with a potassium-based internal solution composed of (in $\mathrm{mm}$ ) $130 \mathrm{~K}$ D-gluconate, $10 \mathrm{KCl}, 10 \mathrm{NaCl}, 10$ HEPES, 0.5 EGTA, $4 \mathrm{Mg}$-ATP, and 0.4 Na-GTP, pH 7.3, adjusted with $\mathrm{KOH}$ (Hashimoto and Kano, 2003; Hashimoto et al., 2009). Fluorescence images were acquired at $30 \mathrm{~Hz}$ using a high-speed Nipkow disk confocal microscope (CSU21, Yokogawa) at room temperature. The $\mathrm{Ca}^{2+}$-dependent fluorescence signals from selected regions of interest were backgroundcorrected and expressed as increases in fluorescence divided by the prestimulus fluorescence $(\Delta \mathrm{F} / \mathrm{F} 0)$ using Igor Pro software (Wavemetrics).

Behavioral tests. All behavioral tests were performed in mice at 10-18 weeks of age. The rotating rod task was basically the same as described previously (Kishimoto and Kano, 2006). The rotating rod (Muromachi Kikai) consisted of a gritted metal roller ( $3 \mathrm{~cm}$ in diameter). A mouse was placed on the roller rotated at $25 \mathrm{rpm}$, and the time it remained on the rotating roller was measured. A maximum of $60 \mathrm{~s}$ was allowed per mouse. The fixed bar test was also basically the same as described previously (Kishimoto and Kano, 2006). The time the animal remained on a wooden bar (6 mm in width, $80 \mathrm{~cm}$ in length, and $40 \mathrm{~cm}$ above the ground) was measured.

Surgeries for eyeblink conditioning were made according to the procedure described previously (Kishimoto and Kano, 2006). Mice were anesthetized using ketamine $(80 \mathrm{mg} / \mathrm{kg}$, i.p.; Sankyo) and xylazine $(20$ $\mathrm{mg} / \mathrm{kg}$, i.p.; Bayer). Four Teflon-coated stainless-steel wires $(100 \mu \mathrm{m}$ in diameter; A-M Systems) were subcutaneously implanted under the left eyelid. Two wires were used to record the electromyographic (EMG) activity of the orbicularis oculi muscle, which is associated with eyelid closure, and the remaining 2 wires were used to deliver the periorbital shock unconditioned stimulus (US). At least $3 \mathrm{~d}$ were allotted from surgery and acclimation to the conditioning chamber. A tone of $450 \mathrm{~ms}$ duration $(1 \mathrm{kHz}, 80 \mathrm{~dB})$ was used as the conditioned stimulus (CS), and the US was an electrical shock with $100 \mathrm{~ms}$ duration ( $100 \mathrm{~Hz}$ square pulses). The US overlapped the CS in time such that the two stimuli terminated simultaneously. The conditioning consisted of a $7 \mathrm{~d}$ acquisition phase and a $4 \mathrm{~d}$ extinction phase. The US intensity was carefully determined as the minimal current amplitude required for eliciting an eyeblink response and constant UR amplitude, and was adjusted daily for each animal. A daily training consisted of 100 trials grouped in 10 blocks. The acquisition sessions consisted of 10 CS-only (every tenth trial) and 90 CS-US paired trials. The extinction sessions consisted of 100 CS-only trials. Intertrial interval was randomized between 20 and $40 \mathrm{~s}$ with mean of $30 \mathrm{~s}$.

The EMG was analyzed as described previously (Kishimoto and Kano, 2006). Briefly, a threshold was determined, and the time window selected for evaluating conditioned response (CR) was $200 \mathrm{~ms}$ before US onset. The ratio of successful CR trials to valid trials was calculated and denoted as the $\mathrm{CR} \%$. The spontaneous eyeblink frequency was measured by 100 "no stimulus" trials before the conditioning experiment began (acclimation phase), and the startle response to a tone was measured during the first 100 trials of the first delay eyeblink conditioning session (day 1). In the pseudoconditioning, CS and US were pseudorandomly presented with an interstimulus interval duration ranging from 0 to $20 \mathrm{~s}$. The intertrial interval duration was randomized between 20 and $40 \mathrm{~s}$, with a mean of $30 \mathrm{~s}$. The time windows used for calculation of eyeblink frequency in the test were the same as those used in the CS-only trials of eyeblink conditioning experiment. UR amplitude was defined as the EMG amplitude at $50 \mathrm{~ms}$ after the US.

Experiments were performed during the light phase of an LD cycle in a container $(10 \mathrm{~cm}$ in diameter) placed in a sound- and light-attenuating 
chamber. Data were analyzed as described previously (Kishimoto et al., 2002). All data are presented as mean \pm SEM.

Statistical analysis. Electrophysiological and calcium imaging data were analyzed with the Microsoft Excel program or SPSS. The statistical analysis was performed by two-way repeated-measures ANOVA with post hoc Bonferroni test, unpaired and paired $t$ test, or Mann-Whitney's $\mathrm{U}$ test, depending on the experimental design. Behavior data were analyzed by a two-tailed Student's $t$ test using the Microsoft Excel program, or by a repeated-measures ANOVA using SPSS. A post hoc comparison was made with the Scheffé test. The difference was considered significant when $p<0.05$.

\section{Results}

\section{Generation of mGluR1b-rescue mice}

Among mGluR1 splice variants, mGluRla possesses a large intracellular C-terminal region consisting of 359 amino acid residues following a seven-transmembrane domain. In mGluR1b, the last 312 amino acid residues of mGluRla are replaced by 20 amino acids (Fig. $1 A, B)$. We introduced a transgene $(L 7-m G l u R 1 b)$ that expressed mGluR1b under the control of the PC-specific $L 7$ promoter into the mGluR1-KO mice (Aiba et al., 1994a) (Fig. 1A,B). We obtained a transgenic line that showed the cerebellum-restricted expression of mGluR1b (Fig. 1C). We refer to these mice as mGluR1b-rescue mice. We also refer to the mice with PC-restricted expression of mGluR1a as mGluR1a-rescue mice (Fig. 1A-C) (Ichise et al., 2000). In situ hybridization analyses of mGluR1b-rescue mice showed that $m G l u R 1 b$ mRNA was expressed only in PCs, whereas mGluR1a mRNA was undetectable (Fig. 1C). Furthermore, immunoreactivity of mGluR1b was restricted to the cerebellar molecular layer in mGluR1b-rescue mice (Fig. 1D).

\section{No Homer and reduced GluR $\delta 2$ in mGluR1b signaling complexes}

We used immunoprecipitation with mGluR1 antibody to examine mGluR1-interacting proteins in the cerebella of mGluRlarescue and mGluR1b-rescue mice. First, we compared the amount of mGluR1b protein in mGluR1b-rescue cerebellum with that of mGluR1a protein in mGluR1a-rescue cerebellum. Western blot analyses using antibodies recognizing the extracellular domain of mGluR1 showed that mGluR1b protein was more abundant in the synaptosomal fraction of the mGluR1brescue cerebella than mGluRla protein of mGluRla-rescue cerebella at postnatal day 15 (P15) and in adulthood (Fig. 2A). Next, we prepared the synaptosomal fraction from the cerebella of WT, mGluR1-KO, mGluRla-rescue, and mGluR1b-rescue mice to identify mGluR1-interacting proteins of these mice. The mGluR1-signaling protein complex was immunoprecipitated with the antibody against the extracellular domain of mGluR1 (Hirata et al., 2012). Subsequently, the complex components were immunoblotted using antibodies against the extracellular domain of mGluR1, Homer (Brakeman et al., 1997; Xiao et al., 1998), GluR $\delta 2$ (Uemura et al., 2004), GABA ${ }_{B} R 2$ (Tabata et al., 2004), and $\mathrm{Ca}_{\mathrm{v}} 2.1$ (Kitano et al., 2003) (Fig. 2B). As expected, Homer proteins were not included in mGluR1b-protein complex in mGluR1b-rescue mice. Furthermore, the amounts of GluR $\delta 2$ in mGluR1b protein complexes were greatly reduced compared with those in mGluR1a protein complexes. Thus, the C-terminal domain of mGluR1a is necessary not only for Homer binding but also for GluR $\delta 2$ binding. By contrast, P/Q type calcium channel $\mathrm{Ca}_{\mathrm{v}} 2.1$ and $\mathrm{GABA}_{\mathrm{B}} \mathrm{R}$ were coimmunoprecipitated efficiently with mGluR1b.
A

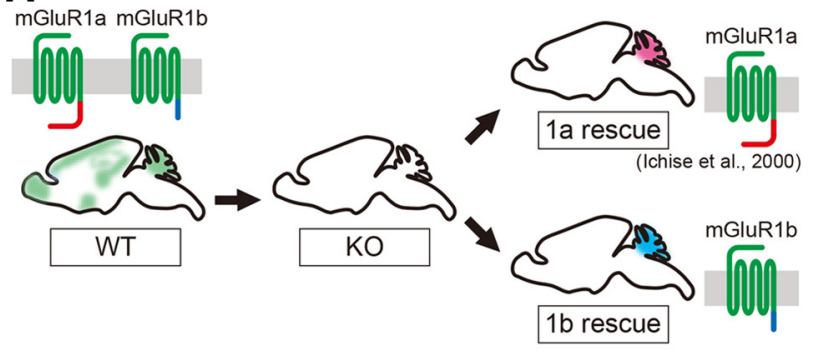

B

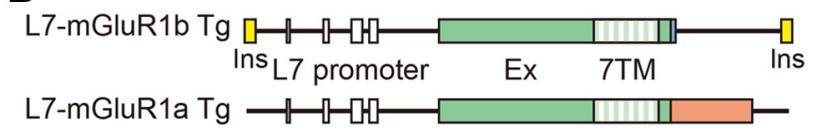

C
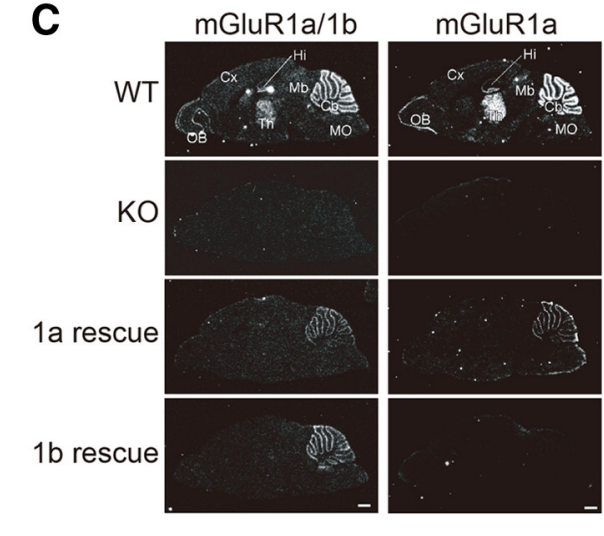

mGluR1b

D

Hematoxylin

anti-mGluR1a
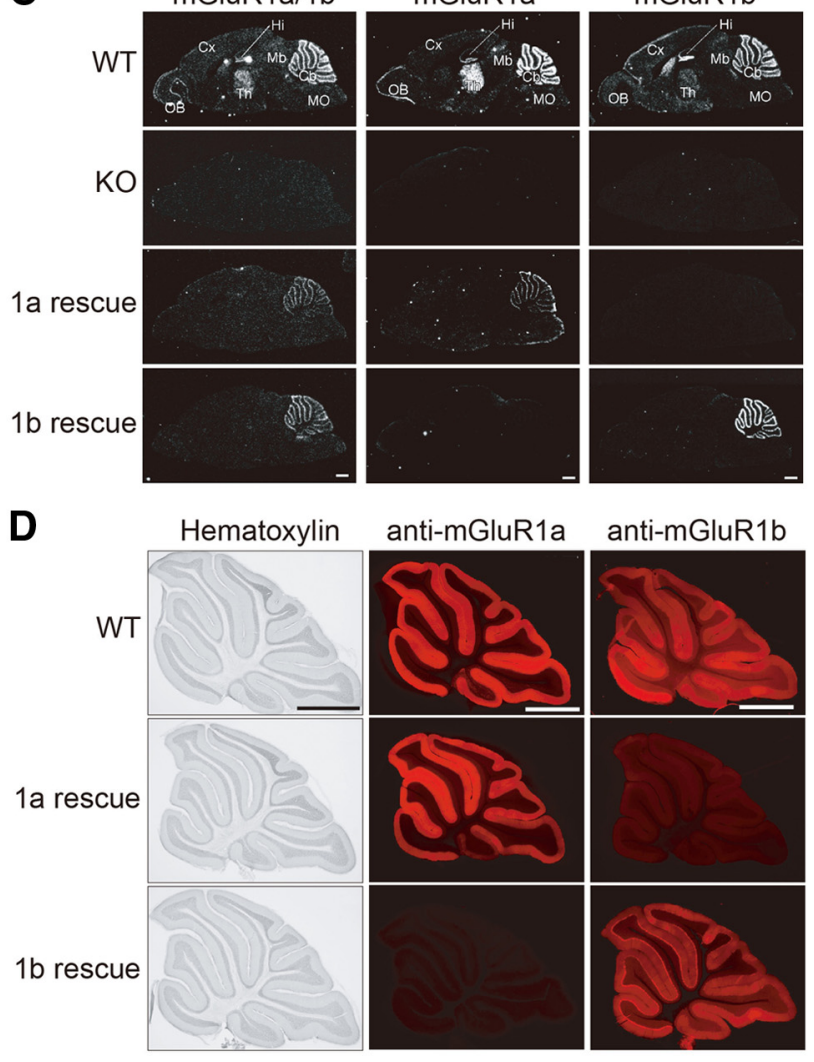

Figure 1. Generation of mGluR1b-rescue mice. A, Strategy for generation of mGluR1arescue and $m G$ luR1b-rescue mice. mGluR1a possesses a large intracellular C-terminal region consisting of 359 amino acids following a seven-transmembrane domain. In mGluR $1 b$, the last 312 amino acids of mGluR1a (red) are replaced by 20 amino acids (blue). mGluR1a-rescue (Ichise et al., 2000) and mGluR1b-rescue mice were generated by introduction of $m G$ I $\mathrm{R} 1$ transgenes under the control of a PC-specific $L 7$ promoter into the mGluR1-KO mice. $B$, Schematic structure of the transgene constructs. Rat $m G l u R 1 b(1 \beta)$ CDNA was inserted into the $L 7$ promoter vector. Open white boxes represent exons of the $L 7$ gene (E1-E4). The first 886 amino acid residues in mGluR1b containing extracellular domain (Ex) and seven-transmembrane domain (7TM) are identical to those of mGluR1a, although in mGluR1b the last 313 amino acids of mGluR1a (red box) are replaced by 20 amino acids (blue box). The $L 7-m G l u R 1 b$ transgene is flanked by an insulator sequence (yellow box) from chicken $\beta$-globin gene to avoid the position effect. C, In situ hybridization analysis of the mGluR1 mRNAs in the brain of WT, mGluR1-K0 (KO), mGluR1a-rescue (1a rescue), and mGluR1b-rescue (1b rescue) mice. Parasagittal sections were hybridized with ${ }^{33}$ P-labeled oligonucleotide probes, which recognize $m G /$ luR1a and/or mGluR1b mRNAs. Cb, Cerebellum; Cx, cerebral cortex; Hi, hippocampus; Mb, midbrain; MO, medulla oblongata; $O B$, olfactory bulb; Th, thalamus. Scale bars, $1 \mathrm{~mm}$. D, Immunohistochemical analysis for mGluR1 proteins. Parasagittal sections from WT (top), mGluR1a-rescue (middle), and mGluR1b-rescue mice (bottom) stained with hematoxylin, antibody to mGluR1a, and antibody to mGluR1b. Scale bars, $1 \mathrm{~mm}$. 


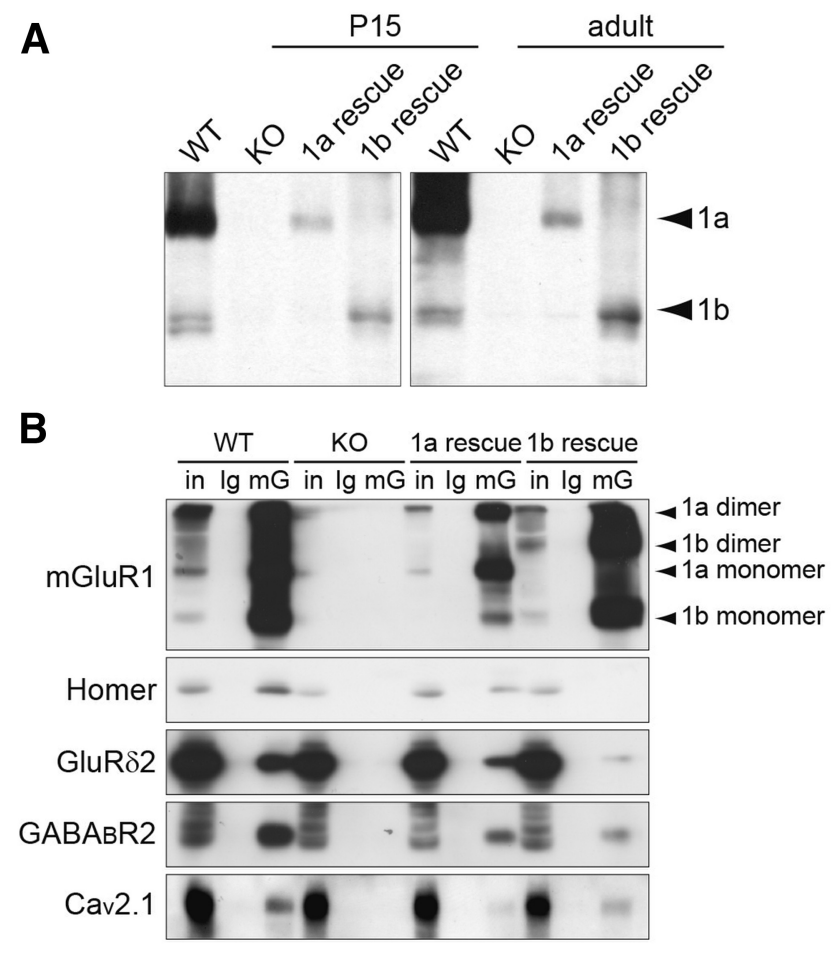

Figure 2. mGluR1-signaling protein complexes from mGluR1a-rescue and mGluR1b-rescue cerebella. $\boldsymbol{A}$, Expression levels of mGluR1 proteins in the cerebella of WT, mGluR1-KO (KO), mGluR1a-rescue (1a rescue), and mGluR1b-rescue (1b rescue) mice. Synaptosomal fractions were prepared from mouse cerebella at $\mathrm{P} 15$ and in adulthood and were immunoblotted with an antibody specific to the extracellular domain of mGluR1 proteins. Arrowheads indicate bands for mGluR1a (1a) and mGluR1b (1b). B, Composition of mGluR1-signaling protein complex. Synaptosomal fraction from the cerebellum of each genotype was incubated with rat monoclonal antibody against the extracellular domain of mGluR1 or rat lgG. Subsequently, the input (in) and the proteins bound to $m G l u R 1$ antibody $(\mathrm{mG})$ and $\lg G(\mathrm{lg})$ were immunoblotted using antibodies against the N-terminal domain of mGluR1, Homer, GluR $\delta 2, G_{A B A} \mathrm{R}_{\mathrm{B}}$, and $\mathrm{Ca}_{\mathrm{v}} 2.1$.

\section{Disturbed subcellular localization of mGluR1 in PC dendrites of mGluR1b mice}

To examine the distribution of mGluR1 in the PC spines, we used postembedding immunogold electron microscopic analysis using mGluR1a- and mGluR1b-specific antibodies (Nakamura et al., 2004). In WT and mGluR1a-rescue PCs, $>90 \%$ of immunogold particles representing mGluR1a were distributed to the plasma membrane in spines forming synapses with PF terminals (Fig. $3 A, B$ ). In contrast, in the PC spines of mGluR1b-rescue mice, the percentage of immunogold particles representing mGluR $1 b$ was reduced to $65.0 \%$ ( 26 of 40 particles from 22 spines in 3 mice), and the rest showed cytoplasmic distribution. This result suggests that traffic of mGluR1b to the plasma membrane is not efficient without mGluR1a. We further assessed the tangential distribution of cell membrane-associated gold particles by measuring the distance from the edge of the postsynaptic density (PSD) to the center of immunogold particles. The peak of immunogold distribution of mGluR1a (24 spines from 3 mice) and mGluR1b (16 spines from 3 mice) in WT PC spines and that of mGluR1a (24 spines from 3 mice) in mGluR1a-rescue PC spines occurred at the edge of the PSD. By contrast, the peak of immunogold distribution of mGluR1b in mGluR1b-rescue PC spines (22 spines from 3 mice) was obscure (Fig. $3 C$ ). These results suggest that mGluR1b is less potent in its distribution to the cell membrane, especially around the edge of the PSD.
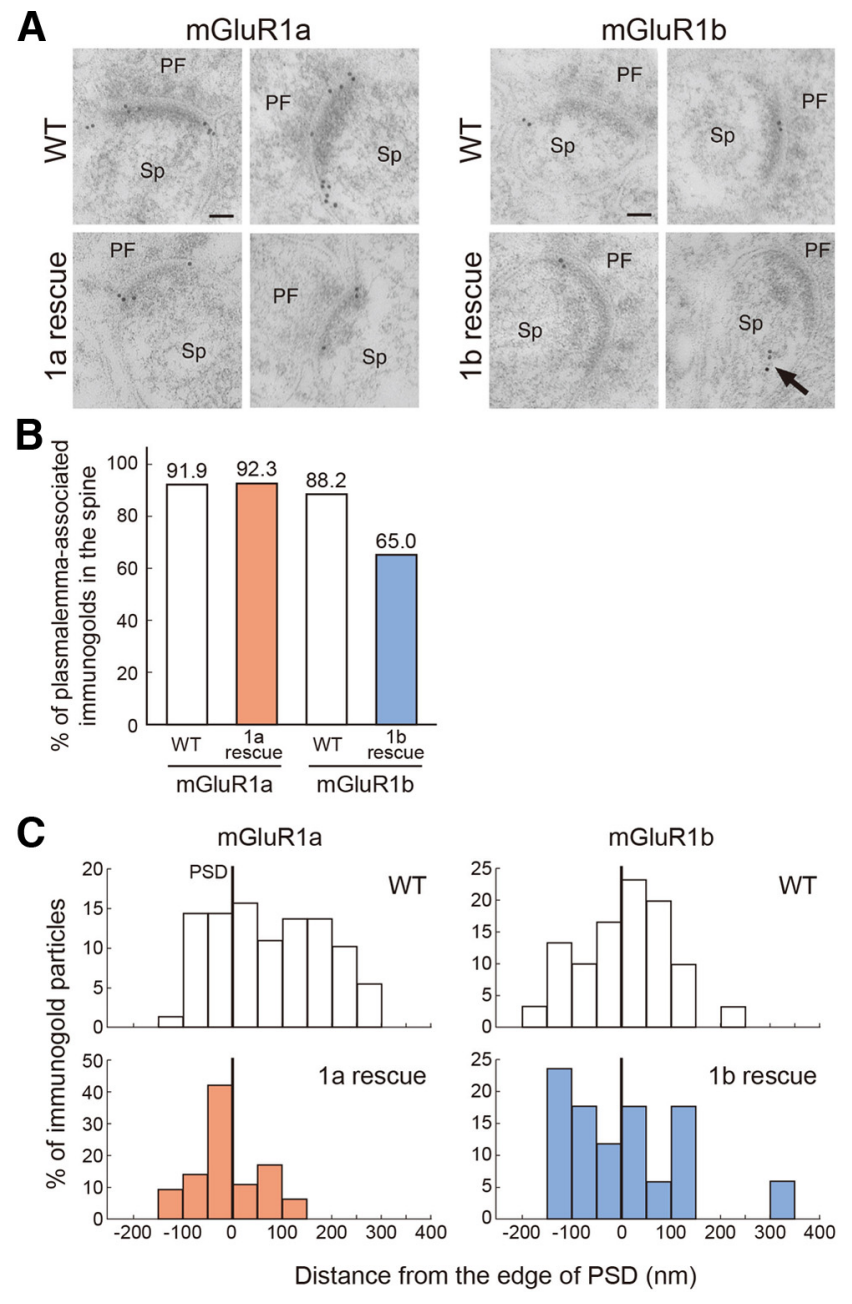

Figure 3. Subcellular localizations of $m G l u R 1$ are disturbed in $P C$ dendrites of $m G l u R 1 b-$ rescue mice. $A$, Left, Postembedding immunogold electron micrographs showing localization of mGluR1a in PC spines in WT and mGluR1a-rescue (1a rescue) mice. mGluR1a labeling was preferential for perisynaptic regions of $\mathrm{PC}$ spines (Sp) contacting $\mathrm{PF}$ terminals in both mice. Right, Electron micrographs showing immunogold localization of mGluR1b in PC spines in WT and mGluR1b-rescue (1b rescue) mice. mGluR $1 b$ labeling was often observed in intracellular (cytoplasmic) compartments (arrow) in mGluR1b-rescue mice. Scale bars, $100 \mathrm{~nm}$. B, Percentage of immunogold particles showing plasma membrane-associated labeling for mGluR1a in PC spines of WT and mGluR1a-rescue (1a rescue) and for mGluR 1 b in spines ofWT and mGluR1b-rescue (1b rescue) mice. Immunogold particles were defined to be plasma membrane-associated when the distance from the center of the gold particle to the cell membrane was $<35 \mathrm{~nm}$. C, Histograms showing tangential distribution of cell membrane-associated immunogold particles for mGluR1a on PC spines of WT and mGluR1a-rescue (1a rescue) and for mGluR1b on PC spines of WT and mGluR1b-rescue (1b rescue) mice. Bold bars represent boundaries of the PSD.

Impaired CF synapse elimination in mGluR1b-rescue mice Persistent multiple CF innervation of PCs in mGluR1-KO mice suggests that mGluR1 is essential for the developmental transition from multi- to mono-innervation of PCs by CFs (Kano et al., 1997). We investigated whether mGluR1b signaling was sufficient for mGluR1dependet CF synapse elimination. The number of CFs innervating the recorded PC was estimated based on the number of discrete CF-EPSC steps elicited in that PC (Fig. 4, insets). CF synapse elimination was severely impaired in mGluR1-KO mice (Fig. 4B) (Kano et al., 1997). The defect was almost restored in mGluRla-rescue mice (Fig. 4C) (Ichise et al., 2000). In marked contrast to mGluRla-rescue mice, CF synapse elimination was impaired in mGluR1b-rescue mice to the same extent as mGluR1-KO mice (Fig. 4B,D). These results indicate that mGluR1b cannot drive the signaling cascades responsible for CF synapse elimination. 


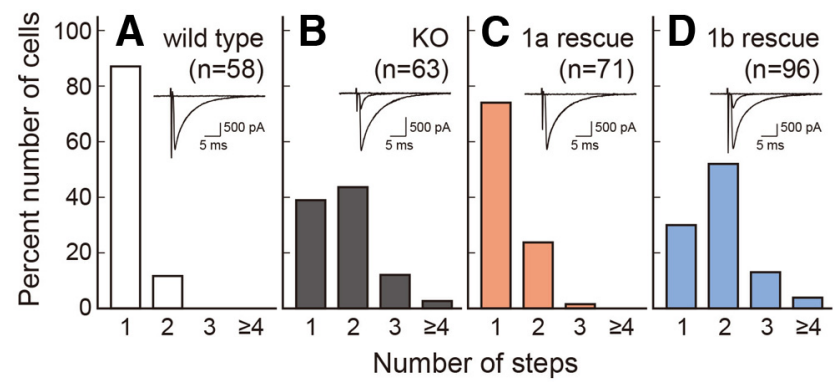

Figure 4. Regression of multiple climbing fiber innervation is impaired in PCs of mGluR1brescue mice. Summary graphs show frequency distributions of $P C s$ in terms of the number of discrete steps of CF-EPSCs from WT mice ( $\boldsymbol{A}, n=58$ from 4 mice), mGluR1-K0 mice ( $\boldsymbol{B}, \mathrm{KO} ; n=$ 63 from 5 mice), mGluR1a-rescue mice ( $C$, 1a rescue; $n=71$ from 5 mice), and mGluR1b-rescue mice ( $\boldsymbol{D}, 1 \mathrm{~b}$ rescue; $n=96$ from 7 mice). Insets, Sample traces of (F-EPSCs from PCS.

\section{Reduced calcium transients and deficient cerebellar LTD in mGluR1b-rescue mice}

An mGluR1/IP 3 R-mediated increase in the dendritic $\left[\mathrm{Ca}^{2+}\right]_{\mathrm{i}}$ is crucial for LTD induction at PF-PC synapses (Aiba et al., 1994b; Conquet et al., 1994; Inoue et al., 1998; Miyata et al., 2001). The kinetics of this signaling appear to depend on the interaction of mGluR1 with Homer proteins (Tu et al., 1998), leading one to expect a difference between mGluR1a and mGluR1b (Fig. 2B). First, we confirmed that dendritic $\left[\mathrm{Ca}^{2+}\right]_{\mathrm{i}}$ transients were evoked by local application of the Group I mGluR agonist DHPG in cultured PCs derived from mGluRla-rescue and mGluR1brescue mice (Fig. $5 A, B$ ). The source of the transients was $\mathrm{Ca}^{2+}$ released from the mGluR1-coupled intracellular store (Sato et al., 2004). The mGluR1a-rescue and mGluR1b-rescue cells displayed similar peak latencies of the $\left[\mathrm{Ca}^{2+}\right]_{\mathrm{i}}$ transients $(3.81 \pm 0.37 \mathrm{~s}, n=$ 16 and $3.21 \pm 0.11 \mathrm{~s}, n=12$, respectively) despite different decay kinetics in cultured PCs (Fig. 5B).

We next examined the mGluR1/IP 3 R-mediated $\left[\mathrm{Ca}^{2+}\right]_{\mathrm{i}}$ transients driven by repetitive PF stimulation in PCs from cerebellar slices (Fig. 5C,D) (Finch and Augustine, 1998; Takechi et al., 1998). The PF synaptic responses in mGluR1b-rescue mice were quite similar to those of mGluRla-rescue mice in synaptic kinetics and paired pulse ratio (Fig. $6 \mathrm{~A}$ ). $\left[\mathrm{Ca}^{2+}\right]_{\mathrm{i}}$ transients elicited in PC dendrites of WT mice by PF train (5 stimuli, $100 \mathrm{~Hz}$ ) comprised two distinct components: an early synaptic $\mathrm{Ca}^{2+}$ transient (ESCT) and a delayed synaptic $\mathrm{Ca}^{2+}$ transient (DSCT) (Takechi et al., 1998). ESCT reflects $\mathrm{Ca}^{2+}$ influx through voltage-gated $\mathrm{Ca}^{2+}$ channels, and DSCT reflects $\mathrm{Ca}^{2+}$ release elicited by $\mathrm{mGluR} 1 / \mathrm{IP}_{3} \mathrm{R}$ activation (Finch and Augustine, 1998; Takechi et al., 1998). The peak amplitude of DSCT increased with the number of stimulus trains (Fig. $5 C, D)$. In mGluR1a-rescue mice, DSCT was not elicited by 5 stimuli at $100 \mathrm{~Hz}$ in most of the PCs (Fig. $5 C, D$ ), but it emerged with $\geq 20$ stimuli. In mGluR1b-rescue mice, this trend was more prominent. Twenty stimuli were still not effective (DSCTs/ESCTs for mGluR1brescue, $9.0 \pm 1.7 \%, n=8$; for mGluRla-rescue, $19.7 \pm 3.0 \%, n=11$; $p<0.05$, $t$ test), and 50 stimuli elicited detectable DSCT in only a half of the cells (Fig. 5C,D).

Given the lower mGluR1/IP ${ }_{3} \mathrm{R}$-mediated $\mathrm{Ca}^{2+}$ release in mGluR1b-rescue mice, we examined the induction of LTD at PF-PC synapses. Because mGluR1b-rescue mice had persistent multiple CF innervations (Fig. $4 D$ ), we locally stimulated the white matter to evoke the maximum CF response for the induction of LTD as reported previously (Miyata et al., 1999). The CF stimulation reliably elicited typical complex spikes that overrode large EPSPs in mGluR1b-rescue mice, and these were indistinguishable from those recorded in mGluRla- rescue mice (Fig. 5G,J). For LTD experiments, we applied conjunctive stimulation of PFs and CFs at $1 \mathrm{~Hz}$ for $5 \mathrm{~min}(300$ pulses), a protocol that is optimal for inducing LTD (Miyata et al., 1999, 2000). In the mGluR1a-rescue mice, LTD of PFEPSPs was readily induced by the conjunctive stimulation. The mean slope of PF-EPSPs was depressed to $78.9 \pm 4.6 \%$ $(n=12, p<0.05$; two-way repeated ANOVA), compared with the control level, at $30 \mathrm{~min}$ after the end of the conjunctive stimulation (Fig. $5 E, F$ ). In contrast, LTD was absent in mGluR1b-rescue mice. The mean slope of PF-EPSPs was $107.6 \pm 6.3 \%(n=12, p>0.05)$ at $30 \mathrm{~min}$ after the end of the conjunctive stimulation (Fig. $5 \mathrm{H}, \mathrm{I}$ ).

\section{Preservation of mGluR1-mediated slow EPSCs in mGluR1b-rescue mice}

In addition to the $\mathrm{IP}_{3} \mathrm{R}$-mediated $\mathrm{Ca}^{2+}$ release from the intracellular $\mathrm{Ca}^{2+}$ stores, mGluR1 stimulation activates TRPC 3 channels in PCs (Hartmann et al., 2008). mGluR1-mediated slow EPSCs elicited by repetitive PF stimulation in PCs are known to be cation currents via TRPC3 (Batchelor and Garthwaite, 1997; Tempia et al., 1998; Hartmann et al., 2008), Thus, we compared the slow EPSCs in PCs of mGluR1a-rescue and mGluR1b-rescue mice. To ensure that approximately the same number of PFs was stimulated in the two types of mice, we first adjusted the stimulus intensity to evoke $\sim 350$ pA PF-EPSCs in the normal ACSF. The EPSCs' amplitudes were $350.0 \pm 27.7 \mathrm{pA}$ and $315.1 \pm 27.0 \mathrm{pA}$ $(n=7$, Fig. $6 A)$ in mGluR1a-rescue and mGluRlb-rescue mice, respectively. And then, the mGluR1-mediated slow EPSCs evoked by repetitive PF stimulation were recorded in the presence of CNQX $(50 \mu \mathrm{M})$. The mGluR1-mediated slow EPSCs were readily induced in mGluR1a-rescue and mGluR1b-rescue mice by repetitive PF stimulation (Fig. $6 B$, black trace) and were completely blocked by bath applications of a Group I mGluR antagonist, CPCCOEt (100 $\mu \mathrm{M})$ (Fig. $6 C$, gray trace). The amplitude of mGluR1-mediated slow EPSCs in mGluR1b-rescue mice was not significantly different from those recorded in mGluR1a-rescue mice at each frequency of the repetitive stimulation, except $50 \mathrm{~Hz}$ (Fig. 6D). For instance, the mGluR1-mediated slow EPSC amplitudes at $100 \mathrm{~Hz}$ of the repetitive stimulation were $152.1 \pm 38.9$ and $167.8 \pm 44.9 \mathrm{pA}$ (mean \pm SEM; $p>0.05$; two-way repeated ANOVA) in mGluR1a-rescue mice and mGluR1b-rescue mice, respectively. These results suggest that the long C-terminal domain of mGluR1a is not essential for mGluR1/TRPC-mediated currents in PCs. Furthermore, we measured TRPC-mediated currents in cultured PCs derived from the mGluR1b-rescue mice (Fig. 7A). The DHPG dose-response relation of the relative amplitudes of the currents was not different between the WT and mGluR1b-rescue cells for the tested range of $0.5 \mathrm{nM}$ to $500 \mu \mathrm{M}$ (Fig. $7 B$ ), indicating that the agonist sensitivity was not altered in mGluR1b-rescue mice.

\section{Restored motor coordination but impaired delay eyeblink conditioning in mGluR1b-rescue mice}

mGluR1b-rescue mice exhibited impairments in $\mathrm{mGluR} 1 / \mathrm{IP}_{3} \mathrm{R}$ mediated $\mathrm{Ca}^{2+}$ release, developmental synapse elimination, and LTD induction, but not in mGluR1/TRPC-mediated currents. To examine how motor coordination and motor learning are affected by the synaptic dysfunction observed in mGluR1brescue mice, we applied these mice for the rotating rod task and delay eyeblink conditioning paradigm.

In the rotating rod task, WT and mGluRla-rescue mice quickly learned how to keep themselves on the rod (Fig. 8A) (Ichise et al., 2000), whereas mGluR1-KO mice fell off immedi- 
ately after the rod began to turn (Fig. 8A) (Aiba et al., 1994b). Interestingly, mGluR1b-rescue mice managed to stay on the rod for $>40 \mathrm{~s}$ by the fifth trial (Fig. $8 A$ ). Repeated-measures ANOVA revealed significant differences among the four genotypic groups (genotype: $F_{(3,37)}$ $=11.414, p<0.001$; session and genotype interaction: $\left.F_{(18,270)}=1.923, p=0.014\right)$. Post hoc analysis indicated that there was no significant difference between the retention time of mGluR1a- and mGluR1brescue mice $(p=0.977)$. Thus, mGluR1b in PCs appears to be enough for normal performance of motor coordination in the rotating-rod task. The fixed bar test also revealed normal motor performance in mGluR1b-rescue mice (Fig. $8 B$ ).

Next, we examined delay eyeblink conditioning. The averaged percentage of the acquired conditioned response (CR\%, an index of learning) was measured in WT, mGluR1-KO, mGluR1a-rescue, and mGluR1b-rescue mice (Fig. 8C). The $\mathrm{CR} \%$ for WT and mGluRla-rescue mice progressively increased to $>70 \%$ during the $7 \mathrm{~d}$ acquisition sessions. The CR indices for mGluR1b-rescue and mGluR1-KO mice, however, were $53.54 \pm 6.60 \%$ and $37.10 \pm 4.20 \%$, respectively, even on day 7 (Fig. $8 C$ ), although mGluR1b-rescue mice showed normal perception (Fig. 8D-G). A repeated-measures ANOVA revealed significant differences among the four genotypic groups (genotype: $F_{(3,45)}=4.422$, $p=0.008$; session and genotype interaction: $\left.F_{(18,270)}=2.337, p=0.002\right)$. Post hoc analysis indicated that no significant difference was detected between the WT and mGluRla-rescue mice ( $p=0.318$ ), but a significant difference was detected between the WT and mGluR1-KO mice $(p<0.0001)$. It is surprising that a significant difference was also detected between the WT and mGluR1b-rescue mice ( $p<$ 0.001 ) because mGluR1b-rescue mice showed restored motor coordination. During the following $3 \mathrm{~d}$ extinction sessions, complete extinction of CR was observed in all groups of mice. These results suggest that expression of mGluR1b in PCs is sufficient for motor coordination but not for motor learning, as tested by delay eyeblink conditioning.

\section{Discussion}

In this study, we determined the role of the long C-terminal domain of mGluRla at both synaptic and behavioral levels. We found that this domain is required for targeting the receptor to the plasma membrane and perisynaptic regions of PC spines, and for efficient mGluR1-mediated $\mathrm{IP}_{3} \mathrm{R}$ signaling, but it is not essential for mGluR1-mediated TRPC3 signaling. We also found that the C-terminal domain of mGluRla is required for LTD induction, developmental CF synapse elimination, and delay eyeblink conditioning. The mGluR1b receptors, which lack this domain, are sufficient
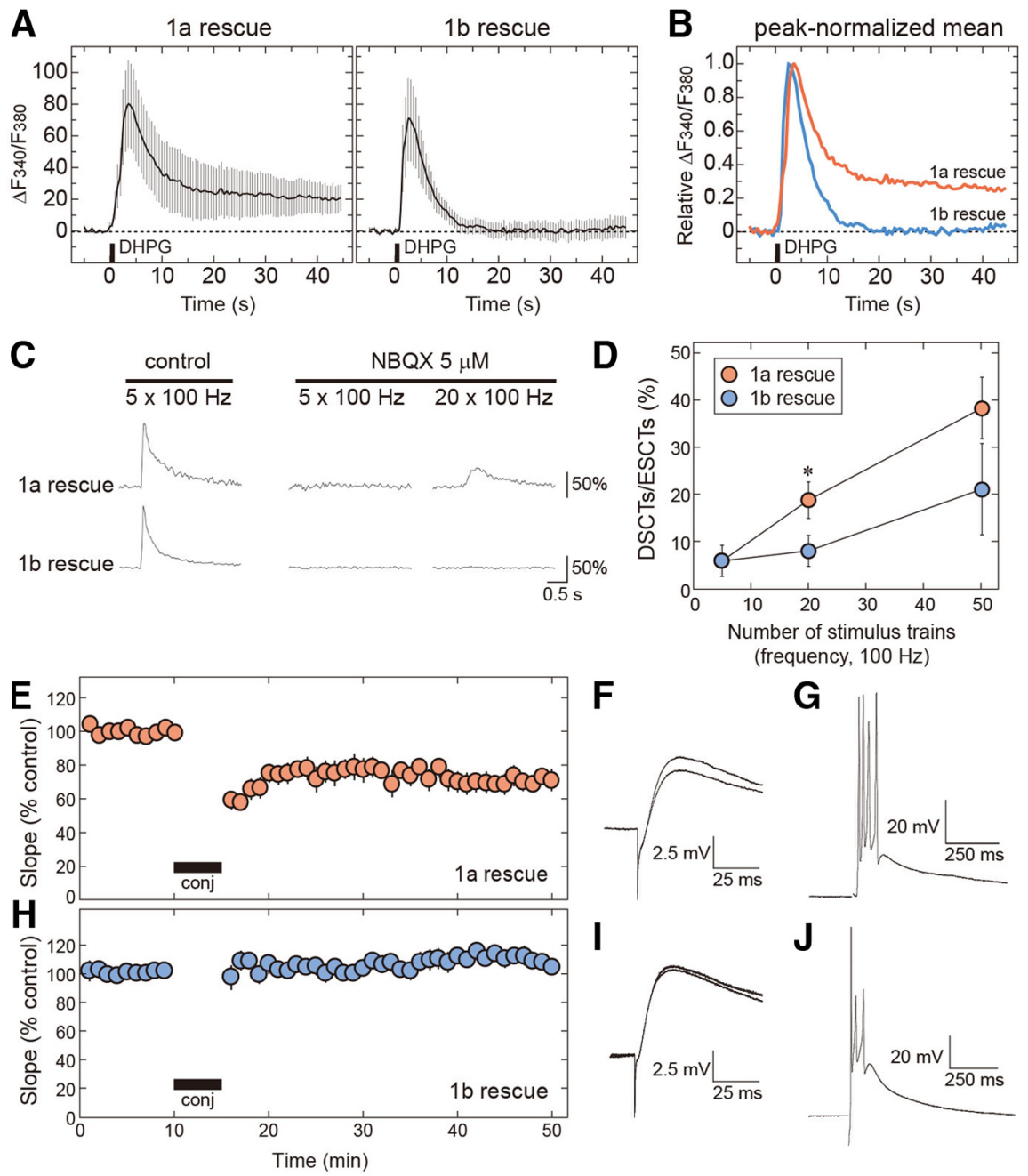

Figure 5. mGluR1-mediated $\mathrm{Ca}^{2+}$ mobilization and LTD are impaired in mGluR1b-rescue mice. $A$, DHPG-evoked $\mathrm{Ca}^{2+}$ mobilization in PCs dissociated from mGluR1a-rescue $(n=16)$ and mGluR1b-rescue $(n=12)$ mice. Traces and error bars indicate mean \pm SEM. $\boldsymbol{B}$, The sustained level (level at 45 s) of DHPG-evoked calcium transient was reduced in mGluR1b-rescue PCs. $\boldsymbol{C}$, Representative traces of $\mathrm{Ca}^{2+}$ transient elicited by repetitive PF train of 5 stimuli (left and middle columns) or 20 stimuli (right column) at $100 \mathrm{~Hz}$ in mGluR1a-rescue and mGluR1b-rescue mice. ESCT was blocked in the presence of NBQX (5 $\mu \mathrm{m}$, middle and right columns). $\boldsymbol{D}$, Summary graph for the dependence of $\mathrm{Ca}^{2+}$ signals on the number of stimuli. Peak amplitudes of DSCTs recorded in the presence of NBQX were normalized by those of ESCTs evoked by 5 stimuliat $100 \mathrm{~Hz}$. The number of cells for each data (s 5-13. ${ }^{*} p<0.05$ (t test). $\boldsymbol{E}-J$, Conjunctive PF and CF stimulation (conj) did not induce LTD of PF-EPSP initial slopes in mGluR1b-rescue mice $(\boldsymbol{H}, n=12)$, whereas LTD was successfully induced in mGluR1a-rescue mice $(\boldsymbol{E}, n=12)$. Test PF stimulation was applied at $0.2 \mathrm{~Hz}$. $\boldsymbol{E}, \boldsymbol{H}$, Time course of averaged PF-EPSP initial slopes in mGluR1a-rescue $(\boldsymbol{E})$ and mGluR1b-rescue mice $(\boldsymbol{H})$. PF-EPSPs before and $30 \mathrm{~min}$ after the conjunctive stimulation. Each trace is the average of five consecutive responses in mGluR1arescue $(\boldsymbol{F})$ and mGluR1b-rescue mice $(\boldsymbol{I}) . \boldsymbol{G}, \boldsymbol{J}$, Sample traces of CF-EPSPs in mGluR1a- rescue $(\boldsymbol{G})$ and mGluR1b-rescue mice $(\boldsymbol{J})$.

for generating TRPC-mediated current and normal motor coordination.

Native mGluR1b complexes that immunoprecipitated from mGluR1b-rescue cerebella contained no Homer proteins and significantly reduced amounts of GluR $\delta 2$ compared with the mGluRla complex. Postembedding immunogold electron microscopic analysis revealed that targeting of mGluR $1 b$ to the plasma membrane at postsynaptic spines was reduced in mGluR1b-rescue PCs. Furthermore, the perisynaptic distribution of mGluR1 in the spines of mGluR1b-rescue PCs was disturbed, whereas the peak of the receptor distribution in mGluRla-rescue PC spines occurred at the edge of the PSD, as observed in WT PCs. Notably, native mGluR1b in WT PC spines showed apparently normal targeting. These results suggest that 
A 1a rescue

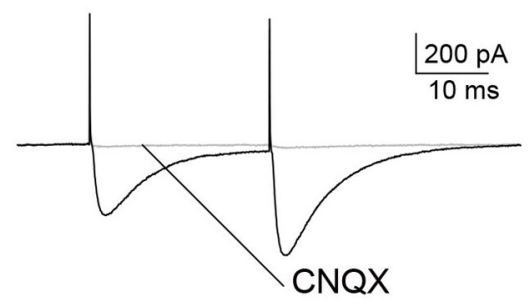

B

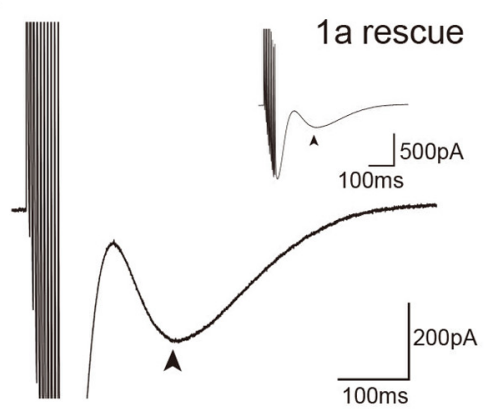

C

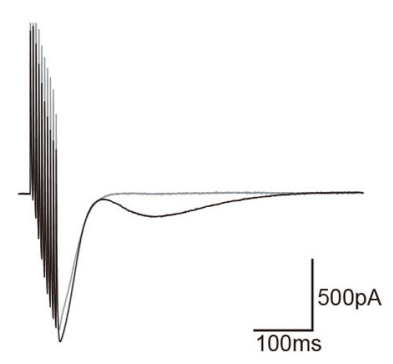

D
$1 \mathrm{~b}$ rescue
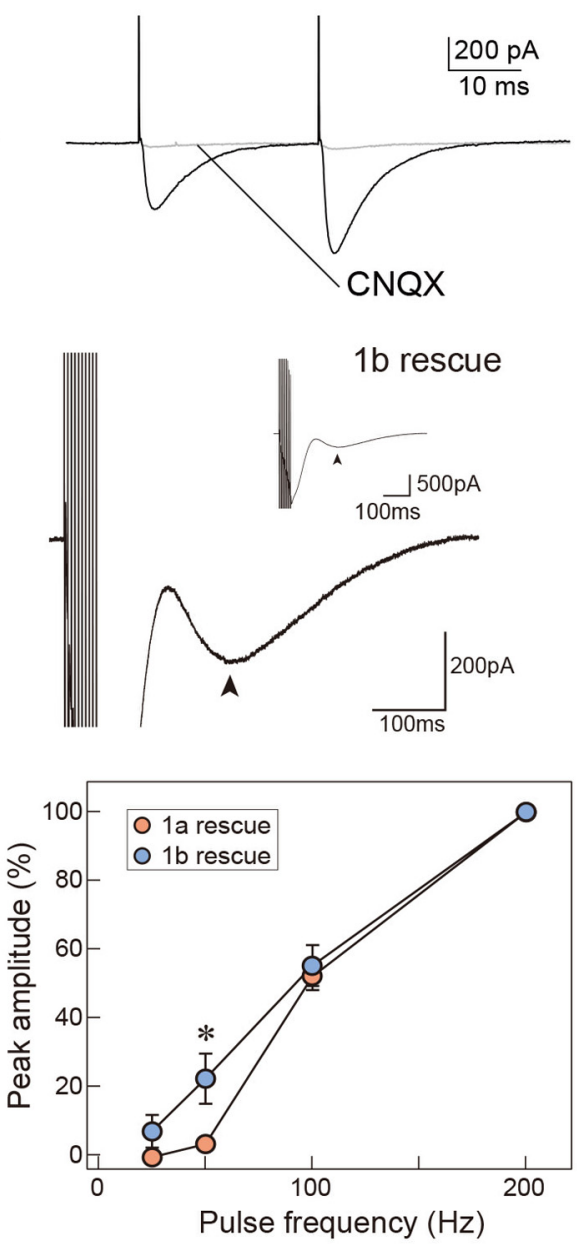

Figure 6. mGluR1-mediated slow EPSCs are normally evoked in mGluR1b-rescue mice. $A$, PF evoked fast EPSCs in mGluR1a-and mGluR1b-rescue mice. Paired PF evoked fast EPSCs (black line, interval of $50 \mathrm{~ms}$ ) in an mGluR1a- (left) and an mGluR1b- (right) rescue mouse before induction of mGluR1-mediated slow EPSCS. PF-evoked fast EPSCs were blocked in both kinds of mice by $50 \mu \mathrm{M}$ CNQX (gray line). B, mGluR1-mediated slow EPSCs (arrowhead) evoked by repetitive PF stimulation ( $400 \mu \mathrm{A}, 10$ pulses) at $200 \mathrm{~Hz}$ in mGluR1a-rescue (left) and mGluR1b-rescue (right) mice. Insets, Complete traces. C, Bath application of an mGluR1 antagonist, CPCCOEt (100 $\mu \mathrm{m}$ ), abolished the mGluR1-mediated slow EPSCs (gray line) in a WT mouse. D, Amplitudes of mGluR1-mediated slow EPSCs are plotted against frequency of PF-stimulation in mGluR1a-rescue and mGluR1b-rescue mice. Pooled data from 7 PCs in both (mean $\pm \mathrm{SEM}$ ). ${ }^{*} p<0.05$ versus mGluR1a-rescue (two-way repeated ANOVA with post hoc Bonferroni test).

A

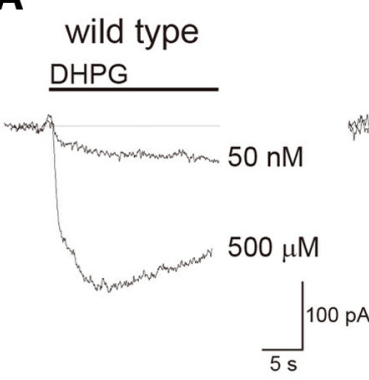

B

\section{$1 \mathrm{~b}$ rescue} DHPG

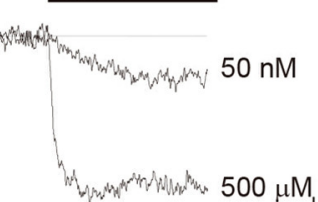

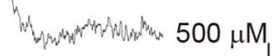

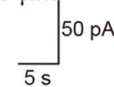

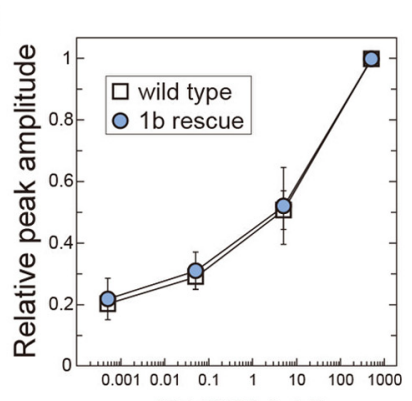

[DHPG] $(\mu \mathrm{M})$

Figure 7. mGluR1-mediated cation currents in cultured PCs from WT and mGluR1b-rescue mice. A, mGluR1-induced cation currents in cultured PCs. The holding potential was set at $50 \mathrm{mV}$ to inactivate depolarization-evoked currents; the cation current was measured as an outward current (outward deflection is indicated as downward to facilitate comparison with the other experiments). Each set of traces indicates the sample current responses of a cultured WT or mGluR1b-rescue $P C$ to the labeled doses of DHPG. DHPG was applied to the whole of the examined cell through a wide-tipped pipette during the period indicated by a thick bar. $B, D H P G$ dose-response relation of cation currents. Dots and error bars indicate means and SEM, respectively $(n=6-9$, WT cells; $n=6-12$, mGluR1b-rescue cells). For each cell, the amplitudes with $0.5 \mathrm{~nm}$ to $5 \mu \mathrm{m}$ DHPG are normalized to the value with $500 \mu \mathrm{m}$ DHPG. The sensitivity to DHPG, an mGluR1 agonist, was not different between WT and mGluR1b-rescue (1b rescue) PCs.

the C-terminal cytoplasmic domain of mGluRla is essential for targeting to plasma membrane and perisynaptic distribution of this receptor. In WT PCs, mGluR1b might form a heterodimer with mGluR1a (Kumpost et al., 2008) and achieve proper targeting to the plasma membrane.

We found that introduction of the transgene expressing mGluR1b did not restore the impairment of $\mathrm{CF}$ synapse elimination in mGluR1-KO mice, whereas the mGluRla transgene restored it. Genetargeted mice deficient in mGluR1, G $\alpha$, PLC $\beta 4$, or PKC $\gamma$ all exhibit impairment of the late phase of CF synapse elimination (Kano et al., 1995, 1998; Offermanns et al., 1997; Ichise et al., 2000). Myosin-Va mutant mice in which $\mathrm{IP}_{3} \mathrm{R}$-bearing SERs are absent in PC spines exhibited a delay of synapse elimination in the developing cerebella (Takagishi et al., 2007). Together with the present results, the C-terminal domain of mGluRla is necessary for efficient activation of the G $\alpha \mathrm{q}-\mathrm{PLC} \beta 4-\mathrm{IP}_{3} \mathrm{R} /$ PKC pathway in PCs that is required for the elimination of redundant $\mathrm{CF}$ synapses.

mGluR1 stimulation activates two different forms of synaptic signaling: $\mathrm{IP}_{3} \mathrm{R}$-mediated $\mathrm{Ca}^{2+}$ release and TRPCmediated cation currents. In our study, both mGluR1a and mGluR1b were capable of releasing $\mathrm{Ca}^{2+}$ from the intracellular $\mathrm{Ca}^{2+}$ stores, although the decay time course of DHPG-induced $\mathrm{Ca}^{2+}$ mobilization was different between mGluR1a- and mGluR1b-rescue cultured PCs (Fig. 5A,B). This indicates a difference in the signaling deactivation and/or inactivation (desensitization) between the splice variants. Some studies report that the G-protein-coupled receptor kinase that interacts with the long C-terminal domain of mGluRla may play an important role in the desensitization of mGluR1a (Dale et al., 2000; Sallese et al., 2000). However, because the G-proteincoupled receptor kinase-mediated desensitization is relatively slow (minutes to hours), the faster decay of mGluR1b response ( $\sim 10 \mathrm{~s}$; Fig. $5 A, B)$ may be attributable to other mechanisms, such as different ligand-receptor dissociation speeds (Flor et al., 1996). On the other hand, the synaptically evoked $\mathrm{IP}_{3} \mathrm{R}$-mediated $\mathrm{Ca}^{2+}$ release by repetitive PF stimulation was largely impaired in mGluR1b-rescue PCs, compared with that in mGluRla-rescue PCs (Fig. 5C,D). The difference between two rescue PCs may be attributed to the difference in the postsynaptic localization of the mGluR1 variants in the two rescue mice; mGluR1a in mGluRla-rescue mice 
A

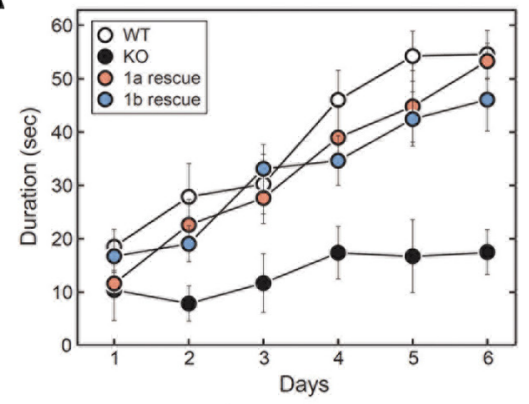

B

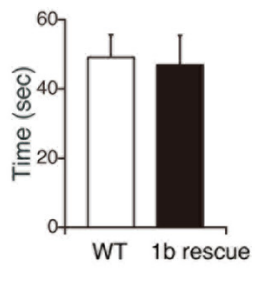

c

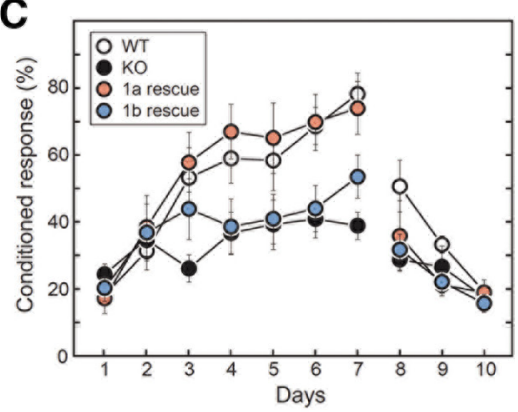

D

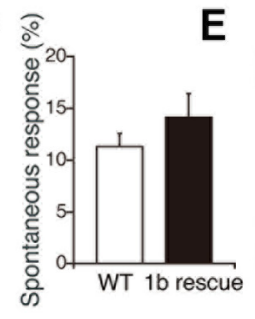

$\mathbf{F}$
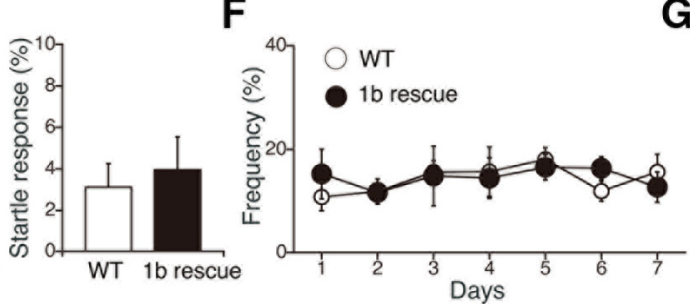

G

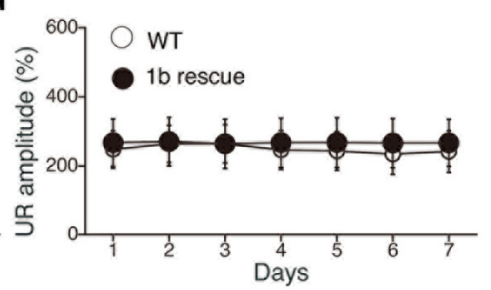

Figure 8. Normal motor coordination but impaired delay eyeblink conditioning in mGluR1b-rescue mice. $A$, Rotating rod task in WT ( $n=12$ ), mGluR1-K0 (K0; $n=8$ ), mGluR1a-rescue (1a rescue; $n=11$ ), and mGluR1b-rescue (1b rescue; $n=10$ ) mice. The stay-time (seconds) of the mice on a rotating rod ( $25 \mathrm{rpm})$ is plotted versus the training day. $\boldsymbol{B}$, Fixed bar test. The time the animal could remain on the wooden bar ( $6 \mathrm{~mm}$ in width and $40 \mathrm{~cm}$ above the ground) was measured. A maximum of $60 \mathrm{~s}$ was allowed per mouse. There was no significant difference between WT (open bar, $n=11)$ and mGluR1b-rescue (closed bar, $n=8)$ mice $(p=0.84)$. C, Percentage of conditioned response (CR) during delay eyeblink conditioning in WT mice $(n=12)$, mGluR1-K0 mice (KO; $n=12$ ), mGluR1a-rescue mice (1a rescue; $n=11$ ), and mGluR1b-rescue mice (1b rescue; $n=14)$. Conditioning experiment consisted of an acquisition phase ( $7 \mathrm{~d}$ ) and an extinction phase ( $4 \mathrm{~d}$ ). mGluR1b-rescue mice exhibited severe impairment of $(R$ acquisition, although learning was fully reinstated in mGluR1a-rescue mice. $D$, Spontaneous eyeblink frequency was measured during 100 "no stimulus" trials in the first session for acclimation before the delay conditioning experiment began. No difference was observed in WT $(n=12)$ and mGluR1b-rescue ( $n=14)$ mice $(p=0.29)$. $\boldsymbol{E}$, The startle response to a tone $C S$ was measured during 100 trials of the first session of delay eyeblink conditioning, indicating that no difference was observed between WT ( $n=12$ ) and $\mathrm{mGluR} 1 \mathrm{~b}$-rescue

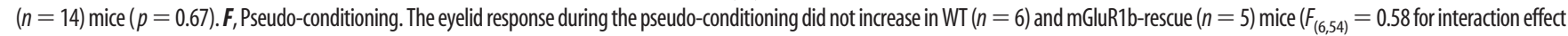
and $p=0.87, F_{(1,9)}=0.030$ for genotypic effect, $p=0.79$ ). The CS and US were pseudo-randomly presented with an interstimulus interval ranging from 0 to $20 \mathrm{~s}$. G, Averaged UR amplitudes for WT ( $n=12$ ) and mGluR1b-rescue $(n=14)$ mice during delay conditioning. In both genotypic groups, the UR amplitudes were nearly constant throughout the $7 \mathrm{~d}$ acquisition phase. No difference was observed between WT and mGluR1b-rescue mice $\left(p=0.59, F_{(6,144)}=0.73\right.$ for interaction effect and $p=0.83, F_{(1,24)}=0.048$ for genotypic effect).

is enriched at discrete perisynaptic sites in the same fashion as the WT mGluR1 (Luján et al., 1997), whereas mGluR1b in mGluR1b-rescue mice was located at ectopic postsynaptic sites. Several lines of evidence indicate that mGluR1 signaling molecules are predominantly distributed at the perisynaptic region of PC spines. For instance, $\mathrm{IP}_{3} \mathrm{R}$-bearing SER extends from the spine apparatus to the outer edge surrounding the PSD in PCs (Harris and Stevens, 1988), and Homer $1 \mathrm{~b} / \mathrm{c}$ is enriched in the region of the lateral PSD (Xiao et al., 1998). In addition, $\mathrm{G} \alpha \mathrm{q} / \mathrm{G} \alpha_{11}$ and PLC $\beta 4$ colocalize at the perisynaptic sites in PC spines (Nakamura et al., 2004). Together, our results suggest that mGluR1a is physically linked to the phosphoinositide signaling complex at perisynaptic regions of PC dendritic spines through interaction between its long C-terminal domain and scaffolding proteins containing Homers. This molecular arrangement presumably ensures high spatial and temporal control of $\mathrm{Ca}^{2+}$ signaling in a PF activity-dependent manner. In contrast, ectopic localization of mGluR1b lacking the long C-terminal domain may result in the difficulty in constructing this signaling complex.

Our results indicate that the long C-terminal domain is not essential for the TRPC-mediated current (Fig. $6 B, D$ ). It is reported that TPRC channels are activated by diacylglycerol at the downstream of the PLC $\beta$-coupled receptor and/or by $\mathrm{IP}_{3} \mathrm{R}$ mediated depletion of intracellular $\mathrm{Ca}^{2+}$ stores (Kiselyov et al., 1998; Hartmann and Konnerth, 2009). Given that IP ${ }_{3} \mathrm{R}$-mediated $\mathrm{Ca}^{2+}$ release was impaired in mGluR1b-rescue PCs, our results strongly suggest that TRPC 3 in PCs is mainly activated by the mGluR1-G $\alpha \mathrm{q}$-PLC $\beta$-diacylglycerol pathway. Our findings also suggest that the perisynaptic localization of mGluR1 is not essen- tial for synaptically evoked mGluR1/TRPC-mediated currents at PF-PC synapses.

We found that introduction of the transgenes expressing mGluR1a, but not mGluR1b, restored impairment of LTD induction in mGluR1-KO mice (Fig. $5 E, H$ ). $\mathrm{IP}_{3} \mathrm{R}$-mediated $\mathrm{Ca}^{2+}$ release from SER in PC spines is essential for the induction of LTD at PF-PC synapses (Miyata et al., 2000). Moreover, a calcium threshold rule for the induction of cerebellar LTD has been proposed (Coesmans et al., 2004). Thus, it is likely that efficient $\mathrm{Ca}^{2+}$ release from SER by mGluR1a is critical for elevating local $\mathrm{Ca}^{2+}$ level in dendritic spines over the calcium threshold for the induction of LTD. A large number of studies using various types of genetically manipulated mice point to a strong linkage between cerebellar LTD and delay eyeblink conditioning, a form of discrete motor learning (Aiba et al., 1994b; Shibuki et al., 1996; Miyata et al., 2001, 2011; Kishimoto et al., 2002; Kishimoto and Kano, 2006; Kakizawa et al., 2007). Among them, mGluR1- and PLC $\beta 4-K O$ mice, whose cerebellar LTD is impaired, exhibit a significant decrease of $\mathrm{CR}$ incidence in the eye blink conditioning paradigm (Aiba et al., 1994b; Miyata et al., 2001; Kishimoto et al., 2002), suggesting that mGluR1-PLC $\beta 4$ signaling is crucial for motor leaning as well as induction of LTD. In this study, we found that LTD and eyeblink conditioning were not restored in mGluR1b-rescue mice, whereas mGluR1a-rescue mice with evidently normal LTD were able to acquire the ability for eyeblink conditioning. These results provide further support for the role of cerebellar LTD in discrete motor learning, such as delay eyeblink conditioning.

It was recently reported that three mutant mice deficient in internalization of AMPA receptors lacked cerebellar LTD ex- 
pression but showed normal adaptation of the vestibulo-ocular reflex, eyeblink conditioning, and locomotion learning (Schonewille et al., 2011). The discrepancy between impaired cerebellar LTD and acquisition of motor learning in these mice suggests the possibility that synaptic plasticity other than cerebellar LTD within or outside of the cerebellum would compensate the loss of cerebellar LTD in motor learning of these mice. Thus, identification of synaptic plasticity induced in these mice would be important for a comprehensive understanding of the molecular mechanisms underlying the motor learning.

mGluR1b-rescue mice displayed apparently normal gait, and there was no significant impairment in their performance in the rotating rod task or fixed bar test, despite the multiple CFs innervating PCs. Our present results from mGluR1b-rescue mice suggest that, although the long C-terminal domain in PCs is required for normal elimination of surplus CF-PC synapses, the C-terminal domain-mediated CF synapse elimination does not directly underlie motor coordination. Hartmann et al. (2008) have proposed that TRPC3 in PCs is essential for normal motor coordination. Thus, almost identical mGluR1/TRPC-mediated currents in PCs expressing mGluR1a and mGluR1b might explain the rescue by these two splice variants from impaired motor coordination in mGluR1-KO mice.

Glutamate-evoked elevation of intracellular $\mathrm{Ca}^{2+}$ required for induction of synaptic plasticity is mainly mediated by NMDA receptors and Group I mGluRs. In this study, we showed that signaling via mGluR1b in PCs is sufficient for TRPC-mediated currents and motor coordination, but not for $\mathrm{IP}_{3} \mathrm{R}$-mediated $\mathrm{Ca}^{2+}$ release, LTD induction, synapse elimination, or delay eyeblink conditioning. These cerebellar functions require proper targeting of $\mathrm{mGluR} 1$ and efficient $\mathrm{mGluR} 1 / \mathrm{IP}_{3} \mathrm{R}$ signaling mediated by the long $\mathrm{C}$-terminal domain of mGluRla. A unique feature of adult PCs is prominent expression of $\mathrm{IP}_{3} \mathrm{R} 1$ (Matsumoto et al., 1996) and very weak, if any, functional NMDA receptor expression (Konnerth et al., 1990; Aiba et al., 1994b; Kano et al., 1995). Whereas mGluRla predominates in PCs and in the olfactory bulb, mGluR1 short variants are the major isoforms in other brain areas (Fotuhi et al., 1993). These molecular distributions imply that mGluRla and $\mathrm{IP}_{3} \mathrm{R}$-mediated $\mathrm{Ca}^{2+}$ release in PCs may replace the glutamate-evoked rise in intracellular $\mathrm{Ca}^{2+}$ through NMDA receptors, which can induce synaptic plasticity in brain regions other than PCs. Other neurons that predominantly express mGluR1 short variants may not require efficient mGluR1a$\mathrm{IP}_{3} \mathrm{R}$ signaling because NMDA receptor-mediated $\mathrm{Ca}^{2+}$ influx dominates in the glutamate-evoked $\mathrm{Ca}^{2+}$ rise.

\section{References}

Aiba A, Chen C, Herrup K, Rosenmund C, Stevens CF, Tonegawa S (1994a) Reduced hippocampal long-term potentiation and context-specific deficit in associative learning in mGluR1 mutant mice. Cell 79:365-375. CrossRef Medline

Aiba A, Kano M, Chen C, Stanton ME, Fox GD, Herrup K, Zwingman TA, Tonegawa S (1994b) Deficient cerebellar long-term depression and impaired motor learning in mGluR1 mutant mice. Cell 79:377-388. CrossRef Medline

Batchelor AM, Garthwaite J (1997) Frequency detection and temporally dispersed synaptic signal association through a metabotropic glutamate receptor pathway. Nature 385:74-77. CrossRef Medline

Brakeman PR, Lanahan AA, O’Brien R, Roche K, Barnes CA, Huganir RL, Worley PF (1997) Homer: a protein that selectively binds metabotropic glutamate receptors. Nature 386:284-288. CrossRef Medline

Coesmans M, Weber JT, De Zeeuw CI, Hansel C (2004) Bidirectional parallel fiber plasticity in the cerebellum under climbing fiber control. Neuron 44:691-700. CrossRef Medline

Conquet F, Bashir ZI, Davies CH, Daniel H, Ferraguti F, Bordi F, Franz-Bacon
K, Reggiani A, Matarese V, Condé F, et al. (1994) Motor deficit and impairment of synaptic plasticity in mice lacking mGluR1. Nature 372: 237-243. CrossRef Medline

Dale LB, Bhattacharya M, Anborgh PH, Murdoch B, Bhatia M, Nakanishi S, Ferguson SS (2000) G protein-coupled receptor kinase-mediated desentization of metabotropic glutamate receptor $1 \mathrm{~A}$ protects against cell death. J Biol Chem 275:38213-38220. CrossRef Medline

Das SS, Banker GA (2006) The role of protein interaction motifs in regulating the polarity and clustering of the metabotropic glutamate receptor mGluR1a. J Neurosci 26:8115-8125. CrossRef Medline

Ferraguti F, Crepaldi L, Nicoletti F (2008) Metabotropic glutamate 1 receptor: current concepts and perspectives. Pharmacol Rev 60:536-581. CrossRef Medline

Finch EA, Augustine GJ (1998) Local calcium signalling by inositol-1,4,5trisphosphate in Purkinje cell dendrites. Nature 396:753-756. CrossRef Medline

Flor PJ, Gomeza J, Tones MA, Kuhn R, Pin JP, Knöpfel T (1996) The C-terminal domain of the mGluR1 metabotropic glutamate receptor affects sensitivity to agonists. J Neurochem 67:58-63. CrossRef Medline

Fotuhi M, Sharp AH, Glatt CE, Hwang PM, von Krosigk M, Snyder SH, Dawson TM (1993) Differential localization of phosphoinositidelinked metabotropic glutamate receptor (mGluR1) and the inositol 1,4,5trisphosphate receptor in rat brain. J Neurosci 13:2001-2012. Medline

Francesconi A, Duvoisin RM (2002) Alternative splicing unmasks dendritic and axonal targeting signals in metabotropic glutamate receptor 1 . J Neurosci 22:2196-2205. Medline

Fukaya M, Hayashi Y, Watanabe M (2005) NR2 to NR3B subunit switchover of NMDA receptors in early postnatal motoneurons. Eur J Neurosci 21:1432-1436. CrossRef Medline

Harris KM, Stevens JK (1988) Dendritic spines of rat cerebellar Purkinje cells: serial electron microscopy with reference to their biophysical characteristics. J Neurosci 8:4455-4469. Medline

Hartmann J, Konnerth A (2009) Mechanisms of metabotropic glutamate receptor-mediated synaptic signalling in cerebellar Purkinje cells. Acta Physiol (Oxf) 195:79-90. CrossRef Medline

Hartmann J, Dragicevic E, Adelsberger H, Henning HA, Sumser M, Abramowitz J, Blum R, Dietrich A, Freichel M, Flockerzi V, Birnbaumer L, Konnerth A (2008) TRPC3 channels are required for synaptic transmission and motor coordination. Neuron 59:392-398. CrossRef Medline

Hashimoto K, Kano M (2003) Functional differentiation of multiple climbing fiber inputs during synapse elimination in the developing cerebellum. Neuron 38:785-796. CrossRef Medline

Hashimoto K, Ichikawa R, Kitamura K, Watanabe M, Kano M (2009) Translocation of a "winner" climbing fiber to the Purkinje cell dendrite and subsequent elimination of "losers" from the soma in developing cerebellum. Neuron 63:106-118. CrossRef Medline

Hirata T, Kumada T, Kawasaki T, Furukawa T, Aiba A, Conquet F, Saga Y, Fukuda A (2012) Guidepost neurons for the lateral olfactory tract: expression of metabotropic glutamate receptor 1 and innervation by glutamatergic olfactory bulb axons. Dev Neurobiol 72:1559-1576. CrossRef Medline

Huttner WB, Schiebler W, Greengard P, De Camilli P (1983) Synapsin I (protein I), a nerve terminal-specific phosphoprotein: III. Its association with synaptic vesicles studied in a highly purified synaptic vesicle preparation. J Cell Biol 96:1374-1388. CrossRef Medline

Ichise T, Kano M, Hashimoto K, Yanagihara D, Nakao K, Shigemoto R, Katsuki M, Aiba A (2000) mGluR1 in cerebellar Purkinje cells essential for long-term depression, synapse elimination, and motor coordination. Science 288:1832-1835. CrossRef Medline

Inoue T, Kato K, Kohda K, Mikoshiba K (1998) Type 1 inositol 1,4,5trisphosphate receptor is required for induction of long-term depression in cerebellar Purkinje neurons. J Neurosci 18:5366-5373. Medline

Ito M (2001) Cerebellar long-term depression: characterization, signal transduction, and functional roles. Physiol Rev 81:1143-1195. Medline

Kakizawa S, Kishimoto Y, Hashimoto K, Miyazaki T, Furutani K, Shimizu H, Fukaya M, Nishi M, Sakagami H, Ikeda A, Kondo H, Kano M, Watanabe M, Iino M, Takeshima H (2007) Junctophilin-mediated channel crosstalk essential for cerebellar synaptic plasticity. EMBO J 26:1924-1933. CrossRef Medline

Kano M, Hashimoto K (2009) Synapse elimination in the central nervous system. Curr Opin Neurobiol 19:154-161. CrossRef Medline

Kano M, Hashimoto K, Chen C, Abeliovich A, Aiba A, Kurihara H, Watanabe M, 
Inoue Y, Tonegawa S (1995) Impaired synapse elimination during cerebellar development in PKC $\gamma$ mutant mice. Cell 83:1223-1231. CrossRef Medline

Kano M, Hashimoto K, Kurihara H, Watanabe M, Inoue Y, Aiba A, Tonegawa S (1997) Persistent multiple climbing fiber innervation of cerebellar Purkinje cells in mice lacking mGluR1. Neuron 18:71-79. CrossRef Medline

Kano M, Hashimoto K, Watanabe M, Kurihara H, Offermanns S, Jiang H, Wu Y, Jun K, Shin HS, Inoue Y, Simon MI, Wu D (1998) Phospholipase C $\beta 4$ is specifically involved in climbing fiber synapse elimination in the developing cerebellum. Proc Natl Acad Sci U S A 95:15724-15729. CrossRef Medline

Kiselyov K, Xu X, Mozhayeva G, Kuo T, Pessah I, Mignery G, Zhu X, Birnbaumer L, Muallem S (1998) Functional interaction between $\mathrm{InsP}_{3}$ receptors and store-operated Htrp3 channels. Nature 396:478-482. CrossRef Medline

Kishimoto Y, Kano M (2006) Endogenous cannabinoid signaling through the CB1 receptor is essential for cerebellum-dependent discrete motor learning. J Neurosci 26:8829-8837. CrossRef Medline

Kishimoto Y, Fujimichi R, Araishi K, Kawahara S, Kano M, Aiba A, Kirino Y (2002) mGluR1 in cerebellar Purkinje cells is required for normal association of temporally contiguous stimuli in classical conditioning. Eur J Neurosci 16:2416-2424. CrossRef Medline

Kitano J, Nishida M, Itsukaichi Y, Minami I, Ogawa M, Hirano T, Mori Y, Nakanishi S (2003) Direct interaction and functional coupling between metabotropic glutamate receptor subtype 1 and voltage-sensitive Cav2.1 $\mathrm{Ca}^{2+}$ channel. J Biol Chem 278:25101-25108. CrossRef Medline

Konnerth A, Llano I, Armstrong CM (1990) Synaptic currents in cerebellar Purkinje cells. Proc Natl Acad Sci U S A 87:2662-2665. CrossRef Medline

Kumpost J, Syrova Z, Kulihova L, Frankova D, Bologna JC, Hlavackova V, Prézeau L, Kralikova M, Hruskova B, Pin JP, Blahos J (2008) Surface expression of metabotropic glutamate receptor variants mGluR1a and mGluR1b in transfected HEK293 cells. Neuropharmacology 55:409-418. CrossRef Medline

Luján R, Roberts JD, Shigemoto R, Ohishi H, Somogyi P (1997) Differential plasma membrane distribution of metabotropic glutamate receptors mGluR $1 \alpha$, mGluR2 and mGluR5, relative to neurotransmitter release sites. J Chem Neuroanat 13:219-241. CrossRef Medline

Mary S, Gomeza J, Prézeau L, Bockaert J, Pin JP (1998) A cluster of basic residues in the carboxyl-terminal tail of the short metabotropic glutamate receptor 1 variants impairs their coupling to phospholipase C. J Biol Chem 273:425-432. CrossRef Medline

Masu M, Tanabe Y, Tsuchida K, Shigemoto R, Nakanishi S (1991) Sequence and expression of a metabotropic glutamate receptor. Nature 349:760765. CrossRef Medline

Matsumoto M, Nakagawa T, Inoue T, Nagata E, Tanaka K, Takano H, Minowa O, Kuno J, Sakakibara S, Yamada M, Yoneshima H, Miyawaki A, Fukuuchi Y, Furuichi T, Okano H, Mikoshiba K, Noda T (1996) Ataxia and epileptic seizures in mice lacking type 1 inositol 1,4,5-trisphosphate receptor. Nature 379:168-171. CrossRef Medline

Miyata M, Okada D, Hashimoto K, Kano M, Ito M (1999) Corticotropinreleasing factor plays a permissive role in cerebellar long-term depression. Neuron 22:763-775. CrossRef Medline

Miyata M, Finch EA, Khiroug L, Hashimoto K, Hayasaka S, Oda SI, Inouye M, Takagishi Y, Augustine GJ, Kano M (2000) Local calcium release in dendritic spines required for long-term synaptic depression. Neuron 28:233244. CrossRef Medline

Miyata M, Kim HT, Hashimoto K, Lee TK, Cho SY, Jiang H, Wu Y, Jun K, Wu D, Kano M, Shin HS (2001) Deficient long-term synaptic depression in the rostral cerebellum correlated with impaired motor learning in phospholipase C $\beta 4$ mutant mice. Eur J Neurosci 13:1945-1954. CrossRef Medline

Miyata M, Kishimoto Y, Tanaka M, Hashimoto K, Hirashima N, Murata Y, Kano M, Takagishi Y (2011) A role for myosin Va in cerebellar plasticity and motor learning: a possible mechanism underlying neurological disorder in myosin Va disease. J Neurosci 31:6067-6078. CrossRef Medline

Nakamura M, Sato K, Fukaya M, Araishi K, Aiba A, Kano M, Watanabe M (2004) Signaling complex formation of phospholipase C $\beta 4$ with metabotropic glutamate receptor type $1 \alpha$ and 1,4,5-trisphosphate receptor at the perisynapse and endoplasmic reticulum in the mouse brain. Eur J Neurosci 20:2929-2944. CrossRef Medline
Oberdick J, Smeyne RJ, Mann JR, Zackson S, Morgan JI (1990) A promoter that drives transgene expression in cerebellar Purkinje and retinal bipolar neurons. Science 248:223-226. CrossRef Medline

Offermanns S, Hashimoto K, Watanabe M, Sun W, Kurihara H, Thompson RF, Inoue Y, Kano M, Simon MI (1997) Impaired motor coordination and persistent multiple climbing fiber innervation of cerebellar Purkinje cells in mice lacking G $\alpha$ q. Proc Natl Acad Sci U S A 94:14089-14094. CrossRef Medline

Pickering DS, Thomsen C, Suzdak PD, Fletcher EJ, Robitaille R, Salter MW, MacDonald JF, Huang XP, Hampson DR (1993) A comparison of two alternatively spliced forms of a metabotropic glutamate receptor coupled to phosphoinositide turnover. J Neurochem 61:85-92. CrossRef Medline

Prézeau L, Gomeza J, Ahern S, Mary S, Galvez T, Bockaert J, Pin JP (1996) Changes in the carboxyl-terminal domain of metabotropic glutamate receptor 1 by alternative splicing generate receptors with differing agonistindependent activity. Mol Pharmacol 49:422-429. Medline

Sallese M, Salvatore L, D’Urbano E, Sala G, Storto M, Launey T, Nicoletti F, Knöpfel T, De Blasi A (2000) The G-protein-coupled receptor kinase GRK4 mediates homologous desensitization of metabotropic glutamate receptor 1. FASEB J 14:2569-2580. CrossRef Medline

Sato M, Tabata T, Hashimoto K, Nakamura K, Nakao K, Katsuki M, Kitano J, Moriyoshi K, Kano M, Nakanishi S (2004) Altered agonist sensitivity and desensitization of neuronal mGluR1 responses in knock-in mice by a single amino acid substitution at the PKC phosphorylation site. Eur J Neurosci 20:947-955. CrossRef Medline

Schonewille M, Gao Z, Boele HJ, Veloz MF, Amerika WE, Simek AA, De Jeu MT, Steinberg JP, Takamiya K, Hoebeek FE, Linden DJ, Huganir RL, De Zeeuw CI (2011) Reevaluating the role of LTD in cerebellar motor learning. Neuron 70:43-50. CrossRef Medline

Shibuki K, Gomi H, Chen L, Bao S, Kim JJ, Wakatsuki H, Fujisaki T, Fujimoto K, Katoh A, Ikeda T, Chen C, Thompson RF, Itohara S (1996) Deficient cerebellar long-term depression, impaired eyeblink conditioning, and normal motor coordination in GFAP mutant mice. Neuron 16:587-599. CrossRef Medline

Tabata T, Sawada S, Araki K, Bono Y, Furuya S, Kano M (2000) A reliable method for culture of dissociated mouse cerebellar cells enriched for Purkinje neurons. J Neurosci Methods 104:45-53. CrossRef Medline

Tabata T, Araishi K, Hashimoto K, Hashimotodani Y, van der Putten H, Bettler B, Kano M (2004) $\mathrm{Ca}^{2+}$ activity at GABAB receptors constitutively promotes metabotropic glutamate signaling in the absence of GABA. Proc Natl Acad Sci U S A 101:16952-16957. CrossRef Medline

Takagishi Y, Hashimoto K, Kayahara T, Watanabe M, Otsuka H, Mizoguchi A, Kano M, Murata Y (2007) Diminished climbing fiber innervation of Purkinje cells in the cerebellum of myosin Va mutant mice and rats. Dev Neurobiol 67:909-923. CrossRef Medline

Takechi H, Eilers J, Konnerth A (1998) A new class of synaptic response involving calcium release in dendritic spines. Nature 396:757-760. CrossRef Medline

Tanabe Y, Masu M, Ishii T, Shigemoto R, Nakanishi S (1992) A family of metabotropic glutamate receptors. Neuron 8:169-179. CrossRef Medline

Tanaka J, Nakagawa S, Kushiya E, Yamasaki M, Fukaya M, Iwanaga T, Simon MI, Sakimura K, Kano M, Watanabe M (2000) Gq protein $\alpha$ subunits $\mathrm{G} \alpha \mathrm{q}$ and $\mathrm{G} \alpha 11$ are localized at postsynaptic extra-junctional membrane of cerebellar Purkinje cells and hippocampal pyramidal cells. Eur J Neurosci 12:781-792. CrossRef Medline

Tempia F, Miniaci MC, Anchisi D, Strata P (1998) Postsynaptic current mediated by metabotropic glutamate receptors in cerebellar Purkinje cells. J Neurophysiol 80:520-528. Medline

Tu JC, Xiao B, Yuan JP, Lanahan AA, Leoffert K, Li M, Linden DJ, Worley PF (1998) Homer binds a novel proline-rich motif and links group 1 metabotropic glutamate receptors with IP3 receptors. Neuron 21:717726. CrossRef Medline

Uemura T, Mori H, Mishina M (2004) Direct interaction of GluR $\delta 2$ with Shank scaffold proteins in cerebellar Purkinje cells. Mol Cell Neurosci 26:330-341. CrossRef Medline

Xiao B, Tu JC, Petralia RS, Yuan JP, Doan A, Breder CD, Ruggiero A, Lanahan AA, Wenthold RJ, Worley PF (1998) Homer regulates the association of group 1 metabotropic glutamate receptors with multivalent complexes of homer-related, synaptic proteins. Neuron 21:707-716. CrossRef Medline 